\title{
EXPERIMENTAL OBSERVATIONS ON THE VERTICAL MIGRATIONS OF PLANKTON ANIMALS
}

\author{
By A. C. Hardy, F.R.S., and R. Bainbridge \\ From the Department of Zoology and Comparative Anatomy, University of Oxford
}

(Plates I and II and Text-figs. I-29)

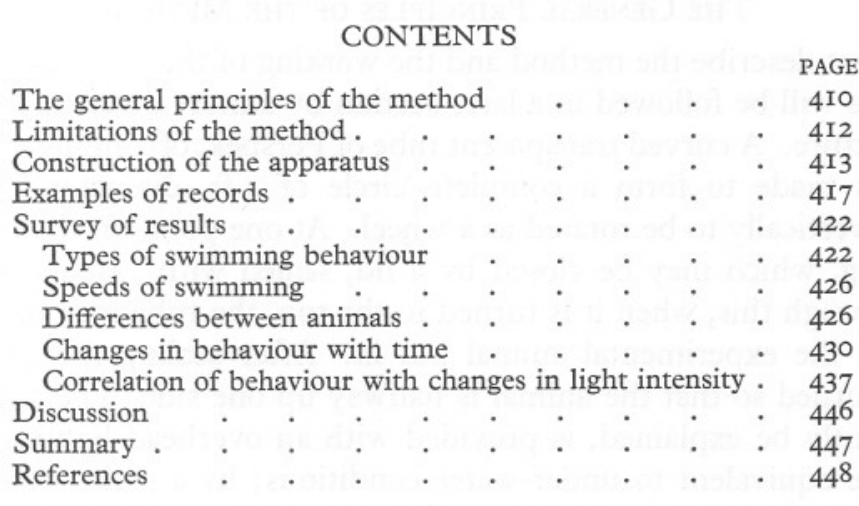

Much information concerning the vertical migration of plankton animals has been gained by using nets at different levels in the sea and at different times of the day and night, and also by experimenting with animals in apparatus of various kinds both in the laboratory and in the sea itself. Such observations and experiments have been summarized in the extensive reviews by Russell (1927) and Cushing (195I) who give full lists of references.

In all this earlier work a limited knowledge of the migrations was obtained by inference. It had not been possible actually to see plankton animals making their extensive upward or downward journeys, so that little was known of how they accomplished them, whether for example by swimming directly and continuously upward or by making more random movements with a general upward tendency. There were no direct data regarding the speed or duration of their climbing and it remained an open question whether they descended passively by sinking or actively by swimming down. Such observations would normally require a vertical column of water of great length. The present paper describes the results of experiments and observations made with a new type of apparatus designed to overcome this difficulty and to give answers to some of these questions. 
Before the war, with the help of a grant from the Leverhulme Trustees, Hardy \& Paton (I947) began studies on vertical migration by using glass cylinders in the sea. This work was interrupted by the war and Neil Paton was killed in action. The Leverhulme Trustees kindly allowed the remaining portion of their grant to be used in the present investigation. The equipment about to be described is related in its origin to the long tube apparatus of the former investigation; it is in fact such a long tube bent in a circle to form a continuous channel of water. A paper describing the apparatus and some of the results obtained with it was given at the Edinburgh meeting of the British Association in I95I and is briefly summarized in Hardy \& Bainbridge (195I $b)$.

\section{The General Principles of the Method}

We will first describe the method and the working of the apparatus in general terms: this will be followed in a later section by a more detailed specification of its structure. A curved transparent tube of Perspex, of 2 in. by $I \frac{1}{2}$ in. crosssection, is made to form a complete circle of $4 \mathrm{ft}$. diameter and is then mounted vertically to be rotated as a wheel. At one point on the rim there is an opening, which may be closed by a lid, sealed with vaseline and bolted down; through this, when it is turned to the top, the tube may be filled with water and the experimental animal put in. After sealing the opening, the wheel is turned so that the animal is halfway up one side. The apparatus, as will presently be explained, is provided with an overhead lighting as nearly as possible equivalent to under-water conditions; by a series of screens the intensity of this light may be varied from bright daylight to darkness. The animal is now free to move upwards or downwards; as it so moves through the water, the wheel is rotated carefully by hand so as to keep the animal opposite a fixed point outside the wheel, i.e. stationary in relation to the observer. It will be seen that the animal is now swimming in an endless column of water; so gradual is the curve, it can go on swimming straight up or down for hundreds of feet provided that the wheel is turned at a corresponding speed (see Text-fig. I, p. 4I4). Inside the tube are small doors, some with weights and some with floats, which automatically open and close as the wheel goes round; they are always wide open on the side at which the animal is swimming, and so do not interfere with it, but are closed on the other side to ensure that the water turns exactly with the wheel and that the movement of this corresponds exactly with that of the animal.

The wheel is mounted in a frame. Fixed to its axle, so as to turn with it, is a pulley having a circumference exactly one-tenth that of the wheel itself; another similar pulley is mounted on the frame below it and a cord, kept at tension by a spring, passes round the two. On this cord is mounted a needle which records on the smoked drum of an electric kymograph. As the animal swims upwards the wheel is turned downwards and so the pulley system 
turns to move the needle upwards exactly one-tenth the distance moved by the animal. A graph at I/Io vertical scale is thus traced on the drum, recording the upward and downward movements of the animal against a time base-line. If the wheel is skilfully turned so as to keep the moving animal always opposite the fixed position outside, its every little movement up or down is faithfully recorded for later analysis. It is in such cases, where the animal is jigging up and down, that the two kinds of doors referred to above are so valuable; they ensure that there is no lag of the water behind the movement of the wheel: it is moved as sharply as the wheel itself, because in each direction the thrust of the water at once meets a door closed tight against a stop. Because of this, together with quickness in following the movements of the animal, the tracing on the smoked paper can be an exact record of the animal's vertical migrational behaviour at a scale of I/IO.

The first experiments were made at the Plymouth Laboratory in a room having a skylight under which the wheel was mounted, the light being varied by a system of screens. It was realized that this was a poor representation of the illumination to be met with in the sea, so that a small glass house (a miniature 'greenhouse') was used for all the subsequent experiments which were carried out at Millport. The sides of it were covered with different thicknesses of paper, to give a graded light from above downwards, and the intensity of the light as a whole could be varied by a series of white, grey and black sheets which could be drawn over the roof and sides. Fixed to the frame, against the wheel and side by side with it, is one quadrant of an exactly similar Perspex tube: this was filled with water and received just the same illumination as the wheel itself. At the lower end of this quadrant, which is exactly opposite the point at which the animal is kept swimming, is fixed a photo-electric cell connected to a sensitive galvanometer which measures the light intensity; these values may be recorded at any moment for correlation with the vertical migrational behaviour of the animal in the tube. When working in darkness, a small red lamp, placed on one side of the tube, enabled the outline of the swimming animal to be kept silhouetted against a dim red disk of light; and thus the movement of the wheel could still be controlled to correspond with the animal's behaviour.

This description of the method will be sufficient to explain in general how the records were obtained and how a single animal can be followed whilst it swims through a column of water corresponding to a vertical height of maybe 200 or $300 \mathrm{ft}$. (as with the large euphausiacean Meganyctiphanes norvegica). The full details of the structure and arrangement of the apparatus will be given later (pp. 4I3-I7). 


\section{Limitations of the Method}

The ease of following an animal while swimming for such long vertical distances is achieved at the cost of certain disadvantages which must be recognized. There are three main limitations. First, conditions differ from those in nature in that as the animal swims upward or downward it does not experience the gradual reduction or increase in pressure that it would do in the sea. Some preliminary experiments have been done (Hardy \& Bainbridge, I95I $a$ ) which appear to show that the behaviour of Calanus finmarchicus is not affected by pressure differences, although with decapod larvae a higher proportion of the population swims upward as the pressure is increased. It is unlikely that the small changes in pressure undergone as the animal swims a matter of a few feet will have an effect on its swimming behaviour, but clearly with forms like decapod larvae the extent of their migration in the apparatus may be very different from what it would be in the sea. Secondly, in the same way in the sea there would be a gradual increase or diminution in the light intensity as an animal swam up or down. This again does not occur in the apparatus, although it can be made to do so roughly either by adjusting screens overhead or by the use of artificial illumination with a dimming device; this, however, could not be in the continuous and gradual manner in which it is experienced in the sea. Thirdly, whilst it is swimming upward or downward in relation to the water passing it, the animal itself is not actually moving upwards because the wheel is turning against it to keep it stationary in relation to the outside world; consequently, if the wheel is turned exactly with the movement of the animal when it begins to swim, it will not experience any acceleration against gravity, i.e. the sensation we get when a lift starts to ascend or descend. This difference from nature will only occur at the moment of starting to rise or fall and will not be experienced once an animal is swimming at a more or less uniform speed. It is a difficulty which in practice is usually automatically overcome because the animal nearly always gets a slight start on the observer when it begins to swim, and the wheel is only subsequently turned to bring it opposite the pointer.

It may perhaps further be suggested that the movement of the animals is to some extent guided in an upward or downward direction by the proximity of the walls of the tube and that the path of swimming we have recorded is an artificial one. This might well be true if we were dealing with a large plankton animal such as a medusa which occupied a good deal of the cross-section of the tube; the plankton animals we are observing here however are so small in relation to the width of the tube that such a 'canalization' of movement does not occur. From time to time an upward swimming animal may converge on to and collide with the side of the tube; when this happens it may often dart away or turn a somersault so that the effect of the walls is rather to delay the upward swimming of an animal instead of guiding it in a vertical direction. 
Animals which swim up diagonally will of course strike the sides more frequently than those which ascend more vertically.

Finally it may be thought that the wall of the tube may affect the swimming of the animals by offering a resistance to the movement of the water when they are swimming close against it. This indeed may have some effect when the animal is very close to the wall but, again because of the small size of the animal in relation to the cross-section of the tube, it will be against the wall only occasionally.

These various limitations must be kept in mind in the interpretation of results, but it is unlikely that they introduce a false representation either of the speed, duration or pattern of swimming behaviour of the animals considered. These factors will be referred to again in the discussion of results.

\section{Construction of the Apparatus}

The apparatus was constructed with the skilled assistance of $\mathrm{Mr} \mathrm{F}$. G. C. Ryder, to whom we are greatly indebted. The tube itself was built up of shaped sections of $\frac{1}{4}$ in. Perspex, the side pieces having been machined to shape and rebated to take the inner and outer pieces which were moulded by heating. The joints were made with chloroform and a solution of Perspex in chloroform and involved no bolting. There are three sectors of tube and these are bolted together with six $2 \frac{1}{2}$ in. 4 B.A. brass bolts through flanges of $I$ in. Perspex attached to the ends of each. The internal dimensions of the tube so formed are $I \frac{1}{2} \times 2$ in., its length is $\mathrm{I} 2 \mathrm{ft}$. and the diameter of the circle it produces roughly $4 \mathrm{ft}$.

This circular tube is mounted on nine wooden spokes by means of Perspex clamps which allow a clearance of $I$ in. between the tube and the wood. The spokes are attached to a boss and an axle which runs on two ball-races supported by a wooden stand (as shown in P1. IA). Even when filled with water the wheel can be rotated with great ease.

A removable Perspex plate covers the filling opening of $I \times \frac{3}{4}$ in. in the outer curved part of the tube. This closing plate is secured by four brass nuts and bolts, the bolts being embedded in a shaped piece of Perspex attached to the main curved section of the tube. The doors or valves, which ensure that the water turns exactly as does the wheel, are fitted in three pairs-one pair at each of the three pairs of flanges. They consist of rectangles of I mm thick Perspex cut to fit the cross-section of the tube exactly, and arranged to swing freely on an axle placed as near as possible to the inner (curved) wall of the tube. One door of each pair has a float made from a hollow cylinder of Perspex (of I cm diameter) attached close to its outer (free) edge and the other member has a weight consisting of a cylinder of lead encased in a hollow cylinder of Perspex attached in a similar position. The automatic action of these weights and floats ensures that the doors are always wide open on the side of the wheel facing the observer, where the animal is swim- 
ming, and closed on the opposite side (Text-fig. I). Their cycle of opening and of closing against small wedge-shaped Perspex stops is shown in Textfig. 2. Originally only one set, of weighted doors, was fitted. These suffice when the wheel is being turned steadily in an anticlockwise direction (when viewed from the right, as in the figures). When the direction of swimming changes, however, and the wheel has suddenly to be turned in the opposite direction, then the inertia of the water causes the doors on the side opposite the observer to be forced open and the movement of the wheel no longer bears a direct relationship to the movement of the animal. The inclusion of a second set of doors working with floats and closing against stops facing the
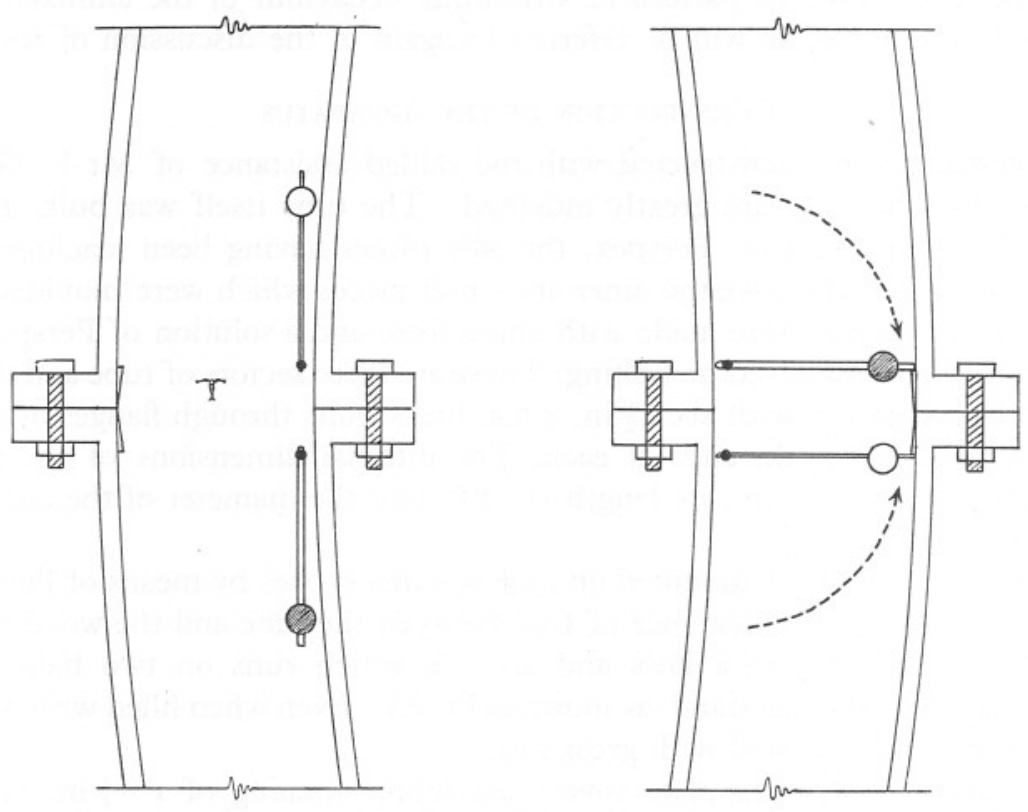

Text-fig. I. Diagram showing the opened and closed positions of the trapdoors at opposite sides of the wheel. A specimen of C. finmarchicus is drawn to scale swimming at the observation side.

opposite way ensures that there is always at least one door closed against a stop in whatever direction the wheel is turned. The efficiency of this method of locking the water to the wheel depends upon the elimination of leakage past the sides of the doors when the direction of rotation is being changed; and upon the free opening and closing of the doors by the forces of gravity. It is essential that the doors should be completely open opposite the observer in order to avoid obstructing the animal; in making the doors loose enough to do this, some slight leakage of water is necessarily entailed, but this is not sufficient to have an appreciable effect on the accuracy of the whole system. 
The recording device consists, as already mentioned, of a large pulley wheel fitted rigidly to an extension of the axle of the wheel on the right-hand side with, below it, a second but free-running pulley of the same size fitted to the side of the wooden stand. The spring-tensioned cord connecting these two pulleys passes along a trackway of $\frac{1}{2}$ in. brass angle, $\mathrm{I} 2 \mathrm{in}$. long, on the side of
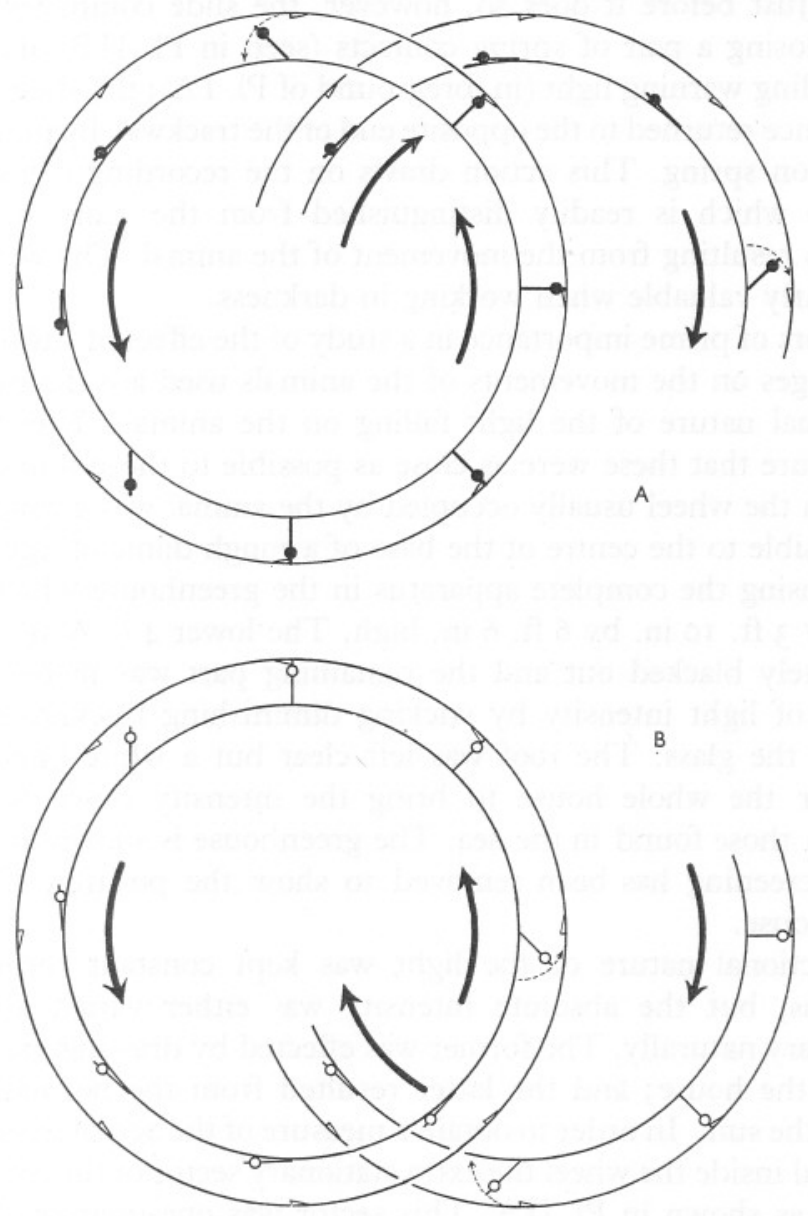

Text-fig. 2. Diagrams showing the cycle of the opening and closing of (A) the weighted doors, and (B) the buoyant doors according to the way the wheel is turned-either clockwise or anticlockwise.

the pulleys away from the observer, and is connected to a slide which runs in the trackway and carries a recording needle. The pulley wheels were made to be precisely one-tenth of the diameter of the Perspex tube (taken from the centre of the tube at one side to the centre at the other) so that the needle moves through one-tenth of the distance swum by the animal and in the same 
direction; in doing so it impinges on an electric kymograph drum carrying smoked paper. By this means a graph representing the movement of the animal is obtained, with time along the horizontal axis and distance swum vertically along the vertical axis. Should the animal swim persistently in one direction then the pointer comes sooner or later to the top or the bottom of the paper. Just before it does so, however, the slide completes an electric circuit by closing a pair of spring contacts (seen in Pl. II B) and so flashes a corresponding warning light (in foreground of Pl. IA); the slide and pointer are then at once returned to the opposite end of the trackway by pulling sharply on the tension spring. This action draws on the recording drum a straight vertical line which is readily distinguished from the more irregular and sloping lines resulting from the movement of the animal. The warning lights are particularly valuable when working in darkness.

Two factors of prime importance in a study of the effect of various environmental changes on the movements of the animals used are the intensity and the directional nature of the light falling on the animal. Every effort was made to ensure that these were as close as possible to those found in nature. The place in the wheel usually occupied by the animal was arranged to be as close as possible to the centre of the base of a rough dome of light. This was done by housing the complete apparatus in the greenhouse which measured $5 \mathrm{ft}$. 9 in. by $3 \mathrm{ft}$. Io in. by $6 \mathrm{ft}$. 6 in. high. The lower $4 \mathrm{ft}$. 6 in. of the walls was completely blacked out and the remaining part was made to transmit a gradation of light intensity by sticking diminishing thicknesses of tissue paper on to the glass. The roof was left clear but a white linen sheet was thrown over the whole house to bring the intensity down to one comparable with those found in the sea. The greenhouse is shown in P1. IB, but the paper screening has been removed to show the position of the wheel inside the house.

The directional nature of the light was kept constant throughout the investigations, but the absolute intensity was either varied artificially or allowed to vary naturally. The former was effected by drawing grey and black sheets over the house; and the latter resulted from the normal passage of clouds over the sun. In order to obtain a measure of the actual intensity falling on the animal inside the wheel the extra stationary sector of tube was mounted alongside it as shown in Pl. IIA. This sector was one-quarter of the whole circle and its lower end, closed with a I mm thick Perspex plate, was arranged to be directly opposite the position occupied by the animal. It was completely

\section{EXPLANATION OF PLATE I}

A. General view of the wheel apparatus for the study of the vertical migration of plankton animals.

B. The apparatus mounted in the small greenhouse; the paper screening designed to give a gradation of light intensity has been removed to show the position of the wheel. 

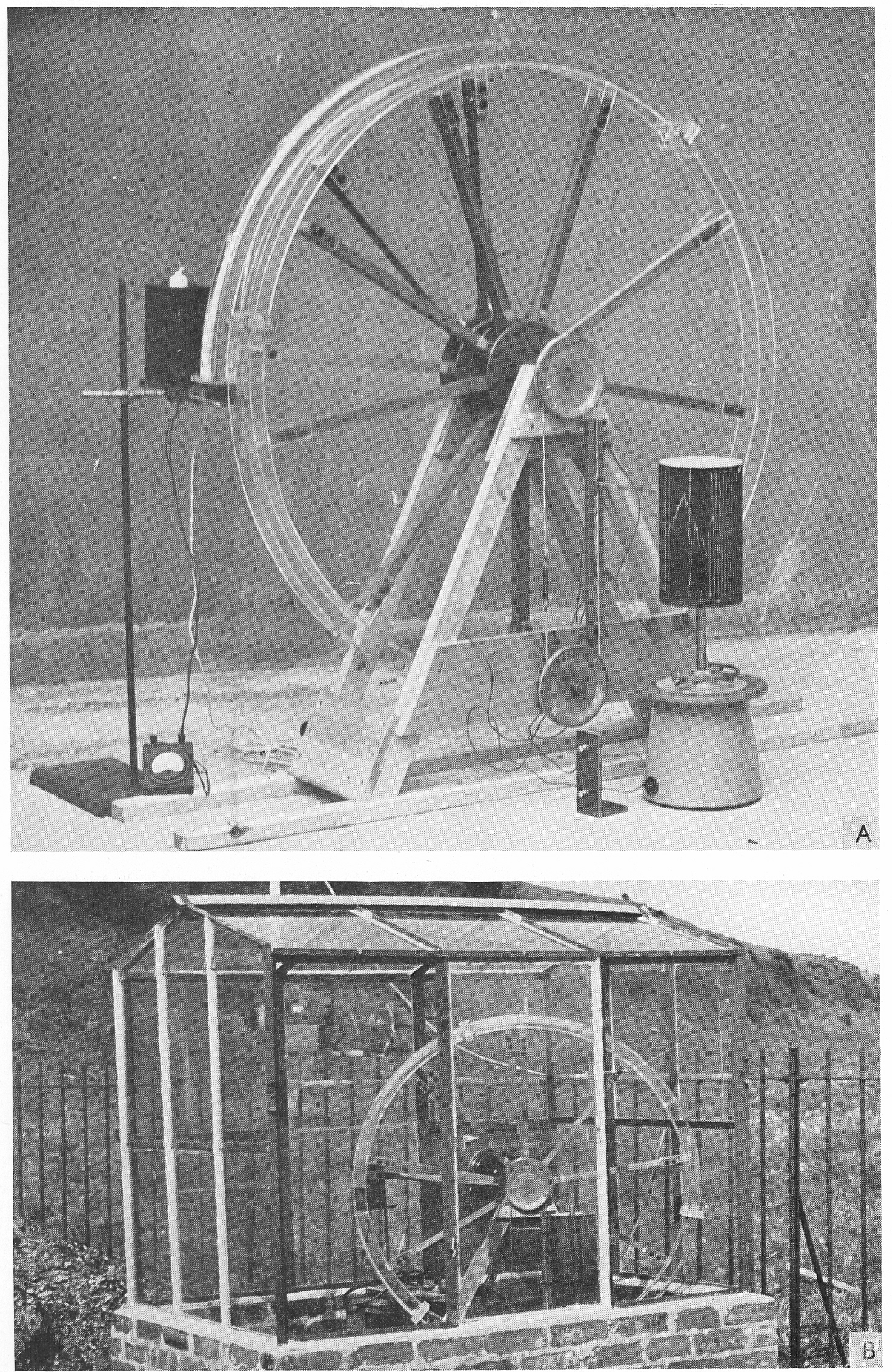

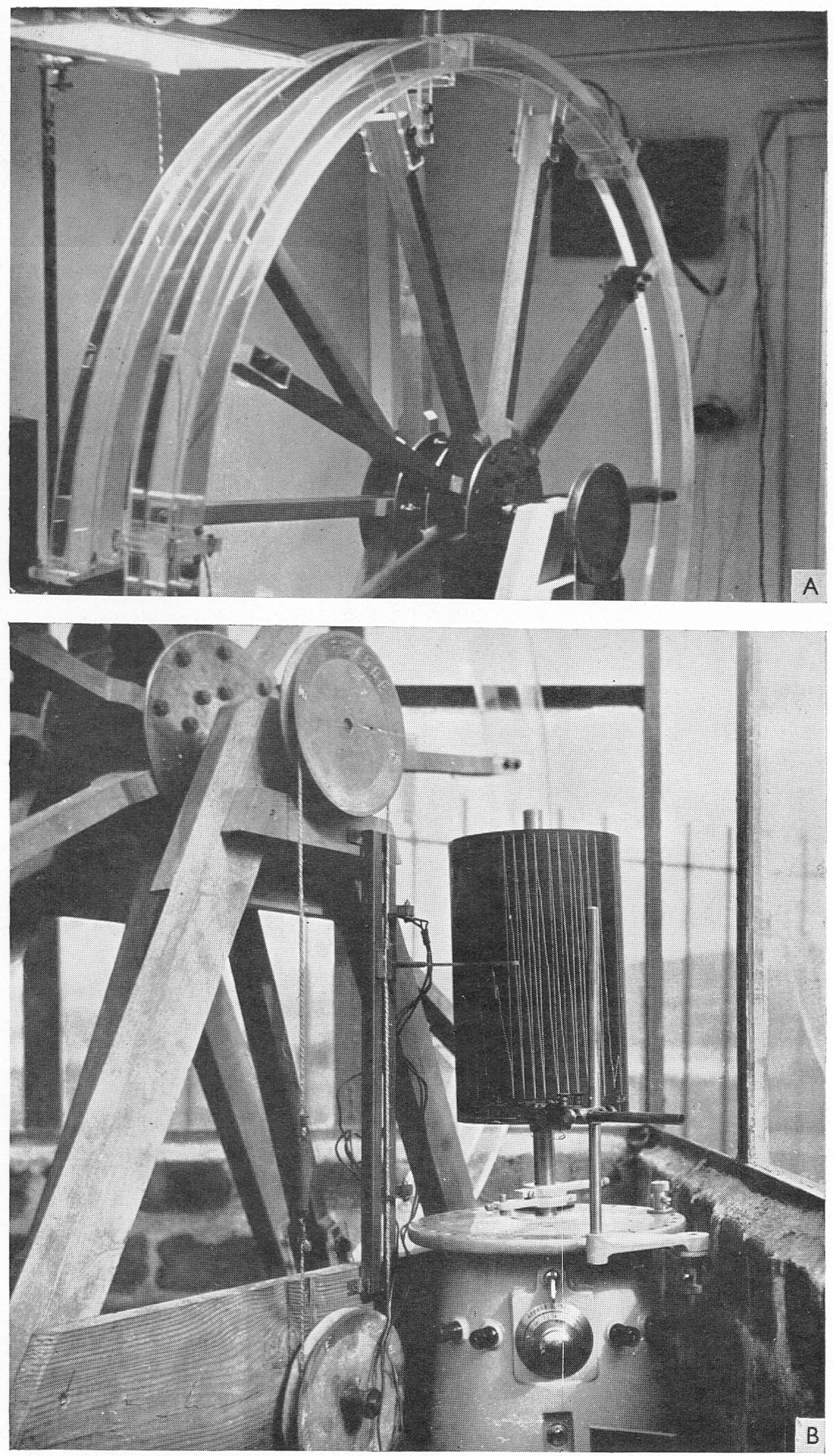
filled with water through a funnel at the top and an Electro-Selenium Photocell was bolted immediately below the Perspex plate and pointed directly upwards. The current produced by this photocell was measured at regular intervals throughout the course of an experiment with a galvanometer, and the current value was used to calculate the light intensity falling on the cell. This is assumed equal to that falling on the animal inside the wheel, because the stationary sector is identical in every respect to a sector of the wheel itself.

In order to use a photocell such as the E.E.L. cell used here for measurement of light intensities, it is necessary for it to be calibrated against a standard cell. This was most kindly and thoroughly done for us by Dr W. R. G. Atkins, F.R.S., of Plymouth, who also gave us valuable advice on the use of cells and circuits. The arrangement finally adopted consisted of an E.E.L. selenium rectifier cell mounted under an opal flashed glass and a Cambridge Unipivot type L galvanometer no. 65542. These were connected with shunts of various value depending upon the light intensity at the time. The galvanometer reads up to $24 \mu \mathrm{A}$, which is equivalent to about $250 \mathrm{Lux}$ of incident light. For light intensities higher than this it is necessary to use a shunt in order to reduce the amount of current passing through the galvanometer. Shunts of 100, 40, and $20 \Omega$ were employed and, with the latter, light intensities up to about ro kilolux could be measured. Unfortunately the current produced by this type of cell varies according to the resistance in the external circuit, and the cell had therefore to be calibrated separately for each shunt. When this was done graphs of scale reading of galvanometer against light intensity were drawn and the conversion of any subsequent experimental reading simply entailed inspection of these.

Use of a greenhouse to obtain the required type of illumination introduced the problem of keeping the apparatus cool. This was accomplished fairly satisfactorily by fitting a Vent Axia fan to draw out the warm air and by watering the roof at intervals with cold water from a watering can. Evaporation from the damp sheet then reduced the temperature considerably.

\section{EXAMPLES OF RECORDS}

The results will be understood more easily if they are introduced by showing and describing a few examples of the records made with the apparatus. Text-fig. 3 shows the first one to be made: that taken at Plymouth on

\section{EXPLANATION OF PLATE II}

A. Detail of the upper part of the wheel to show the extra parallel quadrant for the measurement of light intensity; note also the buoyant and weighted doors in the open position inside the wheel on either side of the sectional junction flanges at the point nearest the camera.

B. Details of the recording mechanism. 


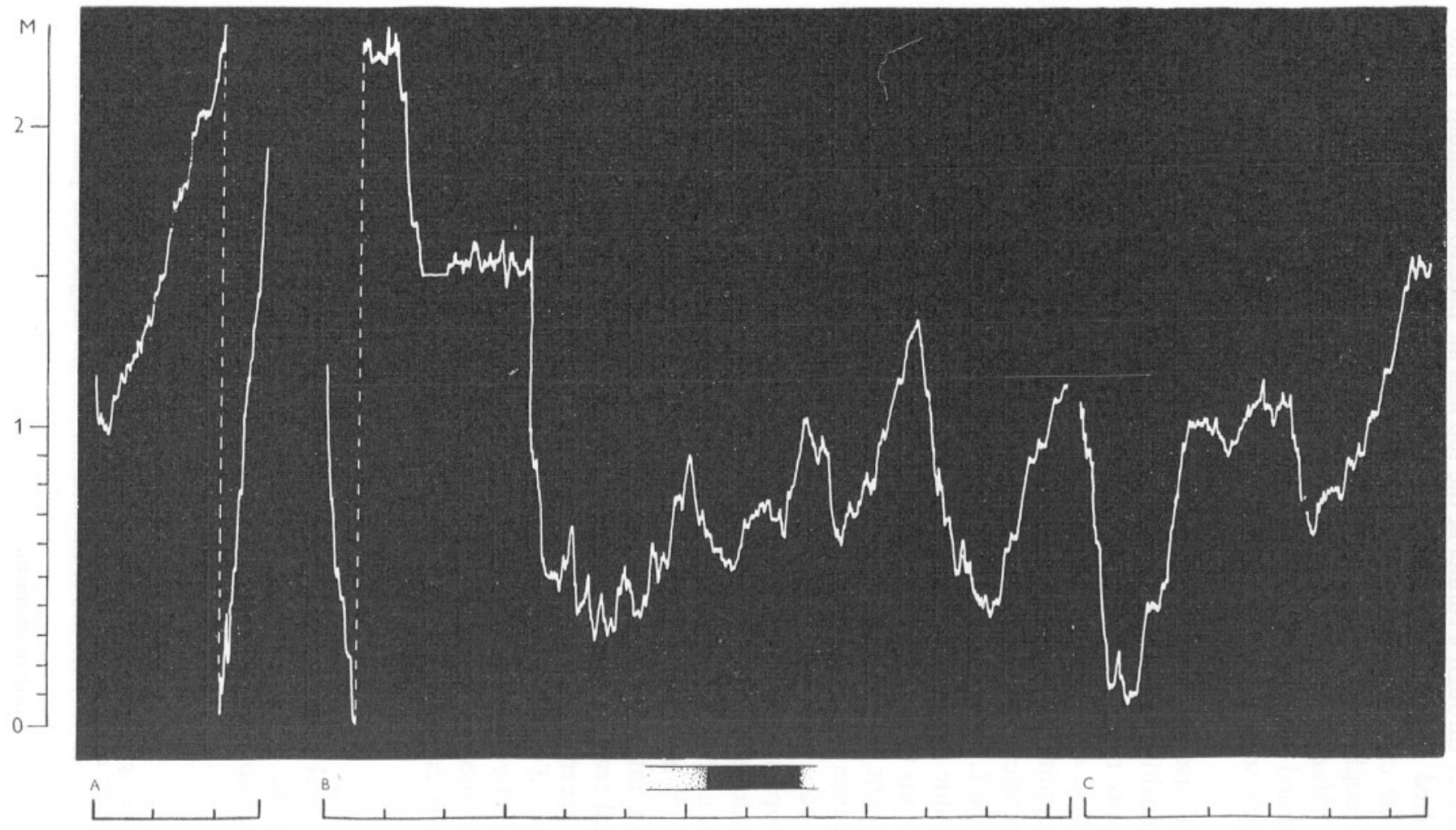

Text-fig. 3. Reproduction of the kymograph tracing obtained in record no. I experimenting with C. finmarchicus. A, a specimen observed from $\mathrm{I} 8.05$ to $\mathrm{I} 8.40 \mathrm{~h}$ on $\mathrm{I} 5$ March $\mathrm{I} 950$; B, a second specimen from I0.5 I to $\mathrm{I2} .55 \mathrm{~h}$ on I6 March I950; , the same specimen from I 4.54 to $15.5 \mathrm{I} \mathrm{h}$ on the same day, the water in the wheel having been enriched with diatoms and flagellates. The time scale is divided into ro min periods (except for period A when the kymograph was rotating more slowly). The blackened and dotted rectangle in B indicates a period of partial and complete blacking out. For full description see text opposite. 
I5-I6 March I950 with the copepod Calanus finmarchicus. It begins with a $35 \mathrm{~min}$ period from $\mathrm{I} 8.05$ to $\mathrm{I} 8.40 \mathrm{~h}$. The smoked paper, from the rotating kymograph drum, is moving to the left at a rate of $2 \mathrm{~mm} / \mathrm{min}$, and, as already explained, the graph traced by the recording needle represents exactly one-tenth of the distance travelled by the animal. In reproduction the graph is further reduced, but a scale shows the actual distance travelled in metres. During this first $35 \mathrm{~min}$ the Calanus, while jigging up and down to a certain extent, is moving upwards with a gradual acceleration; it climbs $0.8 \mathrm{~m}$ in the first half of this period and $2.32 \mathrm{~m}$ in the second half. The broken vertical lines represent where the recording needle has been moved from the top to the bottom of the paper, or vice versa. The second part of the record is made from IO.5I to $\mathrm{I} 2.55 \mathrm{~h}$ on the following day. Calanus, a different specimen, now descends rapidly $\mathrm{I} \cdot 25 \mathrm{~m}$ then jigs up and down for Io $\mathrm{min}$, descends again $0.75 \mathrm{~m}$, remains quite stationary for $5 \mathrm{~min}$ and then jigs again for another $18 \mathrm{~min}$ before diving down, swimming head first, for another metre. From now until this part of the record was stopped at I2.55 the Calanus rises and falls with little bursts of active swimming followed by short intervals of passive sinking or, occasionally, downward swimming; for alternating periods the movement is more upward than downward and vice versa, producing the main peaks and troughs shown on the graph. Halfway through this period the light from above was gradually blacked out to complete darkness for $15 \mathrm{~min}$ and then gradually restored again, as shown in the figure; this change in light intensity appeared to have no effect upon the behaviour of the animal. The last part of the record was taken for just under an hour, I4.54 to $\mathrm{I} 5.5 \mathrm{I} \mathrm{h}$, with the Calanus in water rich in diatoms and flagellates (added from cultures): it swims downwards at first for nearly I $\mathrm{m}$, then upwards, jigs for a time and then downwards again for $0.5 \mathrm{~m}$ followed by an irregular upward movement.

The second example is record no. 4 made, also at Plymouth, on 30 March I950 and shown in Text-fig. 4. Here from II.30 to I3.IO h we are following the movement of a group of Balanus nauplii which kept together as a cluster and swam upwards with great regularity. We are not following one individual all the time, for in the cluster it was difficult to be certain which one was which, as they swam near each other and passed and repassed one another. But because they kept so well together the graph does in fact closely represent the path taken by one individual. The speed of swimming and the energy displayed are surely remarkable for such small animals; for, during the I h 40 min they were observed, they never stopped swimming and averaged a climb of $14.9 \mathrm{~m} / \mathrm{h}$. The speed of ascent of the cluster as a whole varied somewhat as is indicated by the distances between the vertical broken lines: in each such interval the cluster has climbed approximately $2.25 \mathrm{~m}$ and the varying times in minutes taken for this distance are 7.5 , II, I0.5, 8.5, 9.5, $9.5,9.5,13.5$, and I2. The wheel was now stopped and without emptying out 
the water a small medusa of about $\mathrm{I} \mathrm{cm}$ diameter, probably a late ephyra stage of Aurelia, was added; during the second part of the record, from I3.52 to $\mathrm{I} 4.54 \mathrm{~h}$, we followed this medusa and not the nauplii which remained in the water with it. The medusa, like the nauplii, was swimming steadily upwards but at a speed of $27 \cdot \mathrm{I} \mathrm{m} / \mathrm{h}$, i.e. nearly twice as fast. Since we were

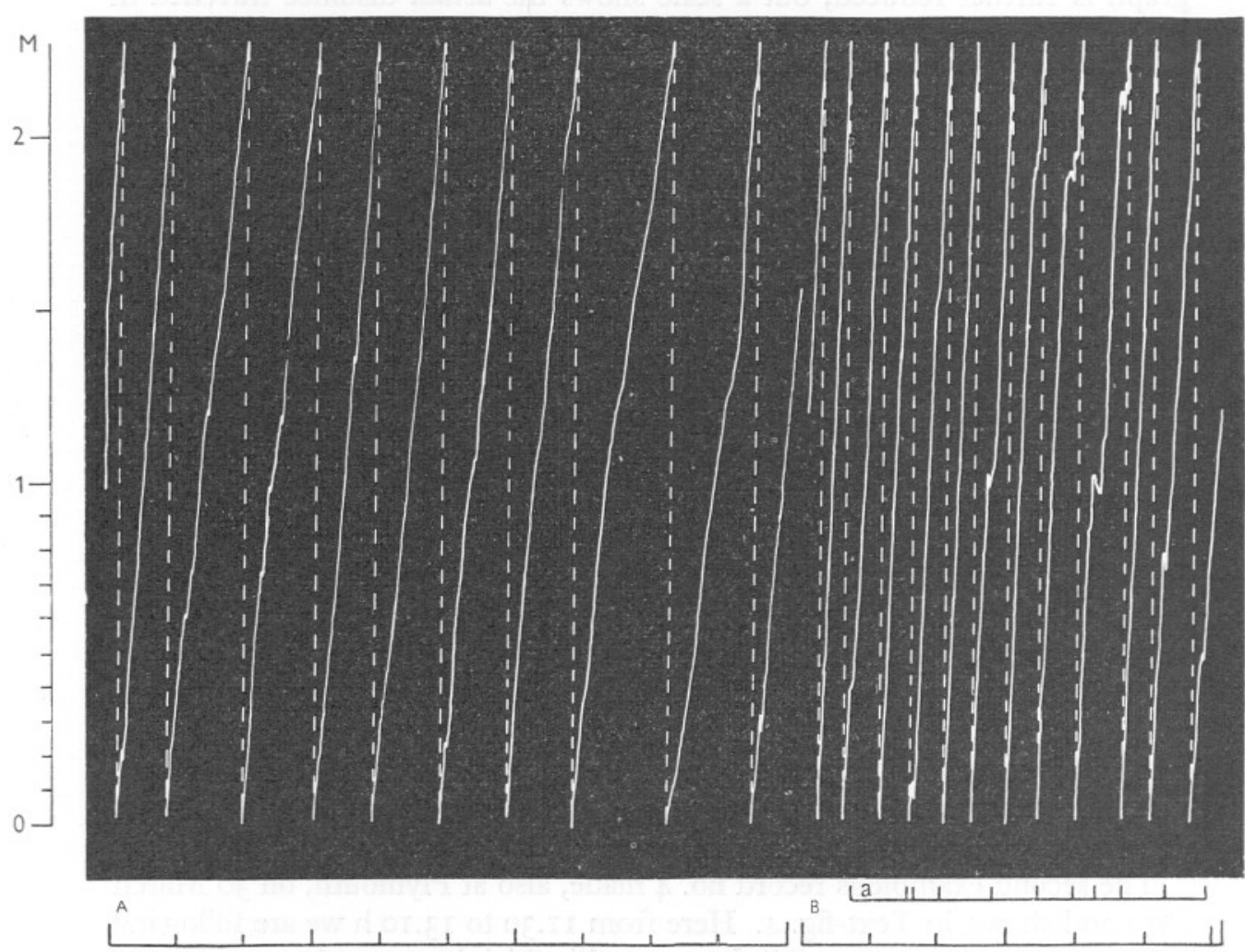

Text-fig. 4. Kymograph tracing from record no. 4. A, showing the upward migration of Balanus nauplii from II.3O to $\mathrm{I} 3 . \mathrm{IO} \mathrm{h}$; $\mathrm{B}$, the upward migration of a small medusa from 13.52 to $14.54 \mathrm{~h}$. The time scale is divided into ro min periods. The line at $a$ indicates pauses for the eating of nauplii: see text on this page.

now keeping pace with the medusa, the nauplii were carried round with the wheel and from time to time were overtaken by the medusa; each time this occurred the medusa stopped for a moment and with a few deft movements of the manubrium snatched up one or two nauplii before proceeding on its way. These pauses are clearly shown on the record as marked below the graph. The position of each nauplius must have been determined by the combined action of the tentaculocysts which presumably were picking up the vibrations in the water made by its swimming movements; each movement of the 


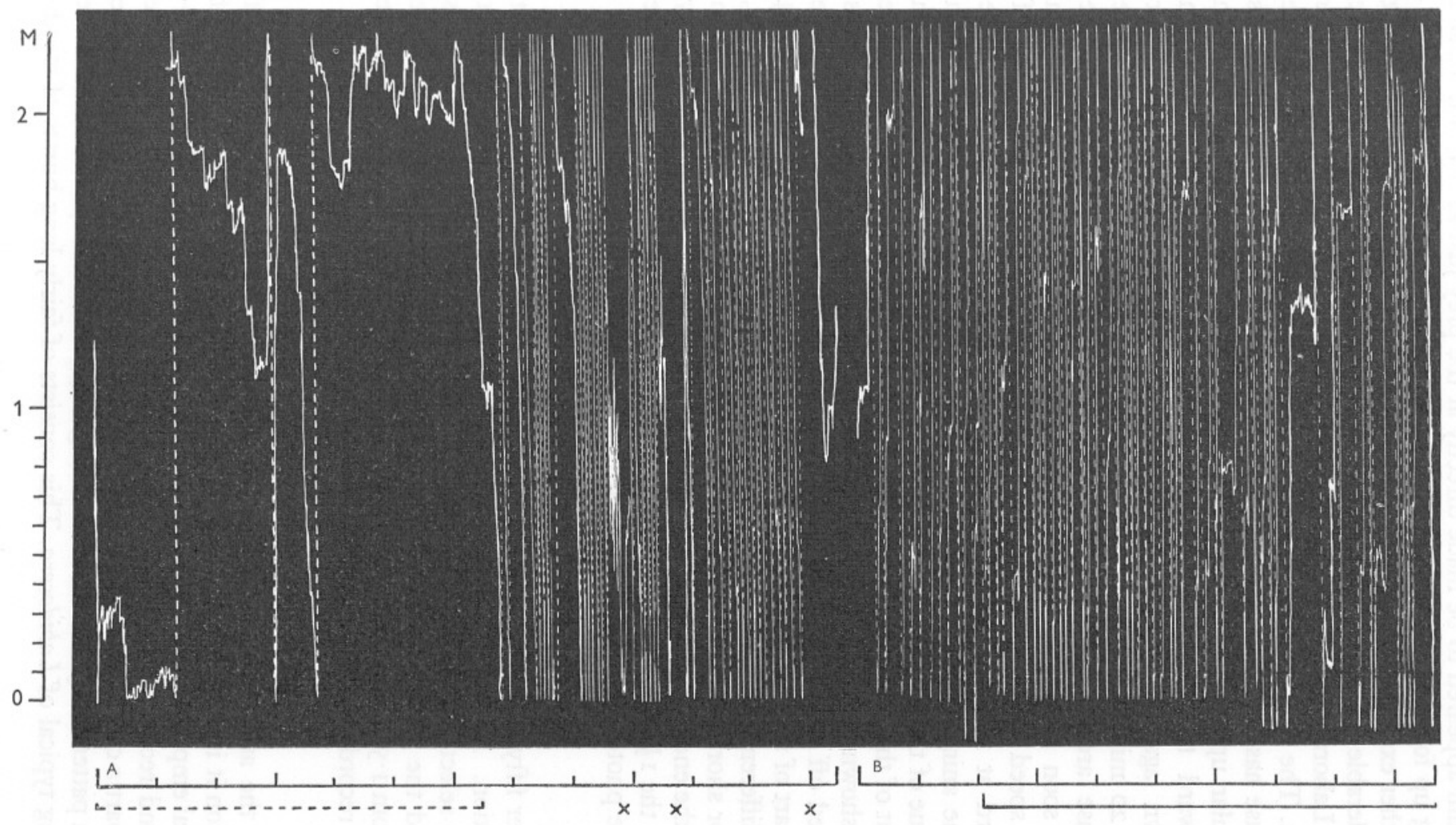

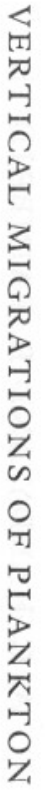

Text-fig. 5. Kymograph tracing from record no. IO. A, showing a medium-sized Meganyctiphanes norvegica observed from I8.45 to $20.50 \mathrm{~h}$; B, a large $M$. norvegica observed from $22.1 \mathrm{I}$ to $23.44 \mathrm{~h}$. The dotted line under A indicates the period during which the ends of the greenhouse were shaded. The crosses indicate occasions when the animal was trapped behind a door. The unbroken line under B indicates the period during which the animal's photophores could be seen glowing. The time scale is divided into ro min periods. See text, p. 422. 
manubrium appeared to be made directly at the prey just as if it was a hand snatching up food in passing.

One other example, Text-fig. 5, will be given to show an animal swimming at considerable speed: record no. Io made in the small greenhouse at the Millport Laboratory on I4 June I950 with the euphausiacean Meganyctiphanes norvegica. The record starts at $\mathrm{I} 8.45 \mathrm{~h}$ with a medium-sized animal and the greenhouse has each end shaded with a black cloth. At first the animal has an irregular up-and-down movement lasting about half an hour but with a downward tendency, then it swims rapidly upwards for about $3 \mathrm{~m}$ and down again for $3 \mathrm{~m}$, after which it swims irregularly again for another $20 \mathrm{~min}$ or so until the dark sheets shading the ends of the greenhouse are removed leaving only the white sheet over the whole top. As soon as this change in lighting is made the animal swims down at great speed and continues to do so until the end of this first part of the record at $20.50 \mathrm{~h}$, except at the points marked with an $X$; at these points the animal, in its headlong downward dash, has accidentally swum behind one of the doors of the wheel and some time has elapsed before it can be got out of this position by jerking the wheel to and fro. This jerking of the wheel is shown on the graph at the first $X$, but later the recording needle has been lifted off the drum whilst these artificial movements were made. The second part of the record was made on the same evening from 22.I I to 23.44 with a different and fully grown specimen of $M$. norvegica. This animal, except for short pauses which become more frequent and of longer duration towards the end, swam rapidly upwards covering a distance of approximately $\mathrm{I} 32 \mathrm{~m}$ in the $\mathrm{I} \frac{1}{2} \mathrm{~h}$. During part of the upward swimming, as indicated on the chart, the photophores could be seen to be shining.

\section{SURVEY OF RESULTS}

Altogether fifty records were made with the apparatus, each averaging about $3 \mathrm{~h}$ duration. It is not proposed to reproduce and describe all of these but rather to select those which best illustrate the various kinds of observations made and the scope of the work as a whole. The kymograph speeds have varied from $\mathrm{I} .5 \mathrm{~mm} / \mathrm{min}$ in some records to $5 \mathrm{~mm} / \mathrm{min}$ in others; a time scale for each record is provided below each tracing reproduced.

\section{Types of swimming behaviour}

While the automatic recording device is making a permanent record of a migration it is possible to make sustained observations on the behaviour of the animal employed. It can then be seen that some animals swim in a characteristic and recognizable fashion; and this movement may be so distinctive as to impart a characteristic pattern to the smoked drum record. An example of such a pattern may be seen in Text-fig. 6 (record no. 28) which shows the swimming typical of Labidocera. This consists of fairly long bursts of steady 
swimming separated by roughly equally long periods of jigging up and down. In contrast, record no. 22 shows, in Text-fig. 7, the steadier swimming of Centropages and record no. Io (Text-fig. 5) the steady and much faster swimming of Meganyctiphanes. A trace typical of a zoea larva is record no. 24, in Text-fig. 8, which shows steady swimming to be possible but also that this may be replaced by an indeterminate bobbing up and down which gives no resultant movement in either direction.
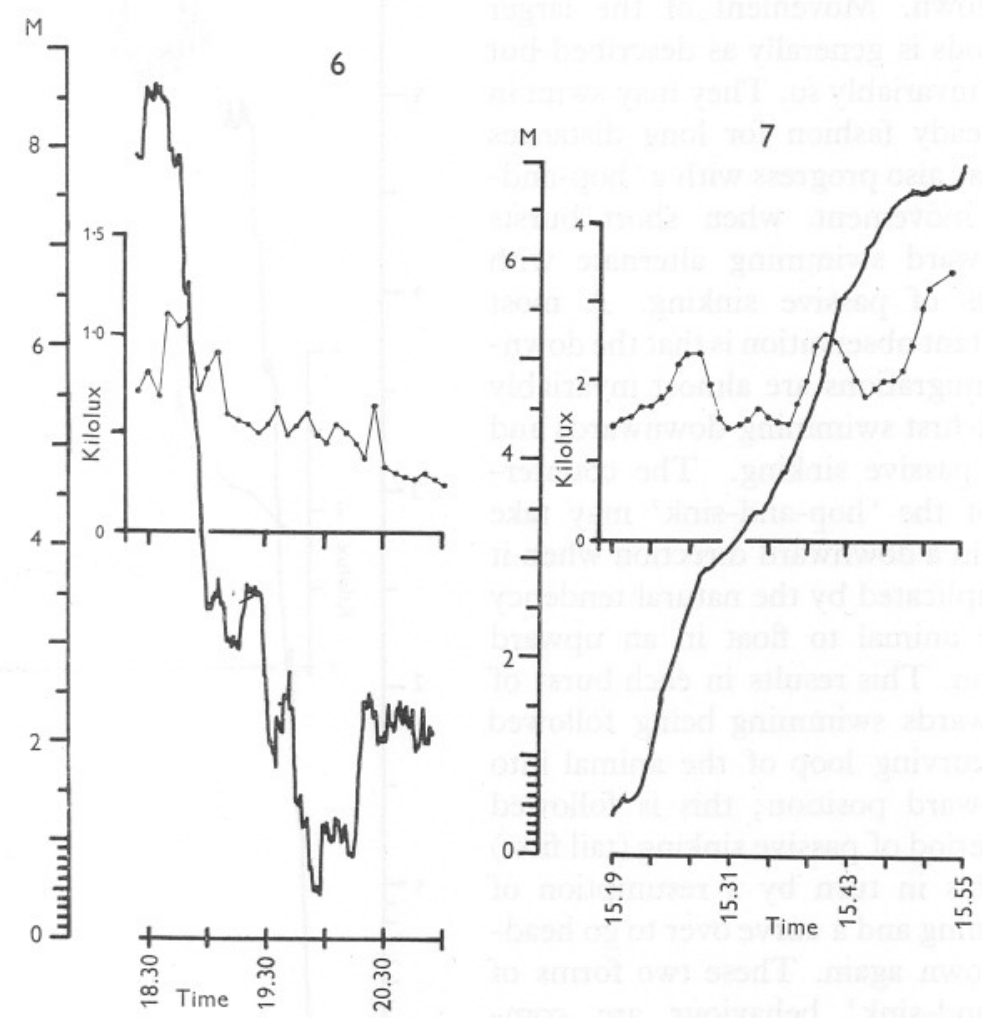

Text-fig. 6. Continuous tracing from part of kymograph record no. 28, showing the

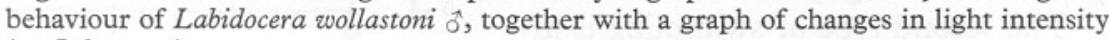
(25 July 1950).

Text-fig. 7. The same of record no. 22, showing the behaviour of Centropages sp. + , but with different scales for time and light intensity (20 July I950).

Generally, amongst the animals used, two distinct types of movement can be distinguished. The first of these is an up-and-down swimming which appears to be quite independent of the nature of the tube; and the second is one with a greater horizontal component which may in fact sometimes entirely replace up-and-down movement. The first type seems to embrace three subdivisions-the direct, the indirect, and the 'hop-and-sink'. The larger 
copepods such as Calanus, Labidocera and Temora swim up and down in a direct manner. Some of the smaller copepods such as Acartia and Paracalanus swim up and down with an indirect motion; i.e. while their resultant movement is in an upward or downward direction they follow an irregular zigzag path, still keeping clear of the sides of the tube but not moving directly up and down. Movement of the larger copepods is generally as described but is not invariably so. They may swim in the steady fashion for long distances but may also progress with a 'hop-andsink' movement, when short bursts of upward swimming alternate with periods of passive sinking. A most important observation is that the downward migrations are almost invariably a head-first swimming downwards and not a passive sinking. The counterpart of the 'hop-and-sink' may take place in a downward direction when it is complicated by the natural tendency of the animal to float in an upward position. This results in each burst of downwards swimming being followed by a curving loop of the animal into an upward position; this is followed by a period of passive sinking (tail first) and this in turn by a resumption of swimming and a curve over to go headfirst down again. These two forms of 'hop-and-sink' behaviour are compared in Text-fig. 9.

The second type of swimming is indulged in by the euphausiids, decapod larvae, and by the larger copepod Euchaeta. These forms, while often making straight up-and-down excursions of the greatest length and speed,

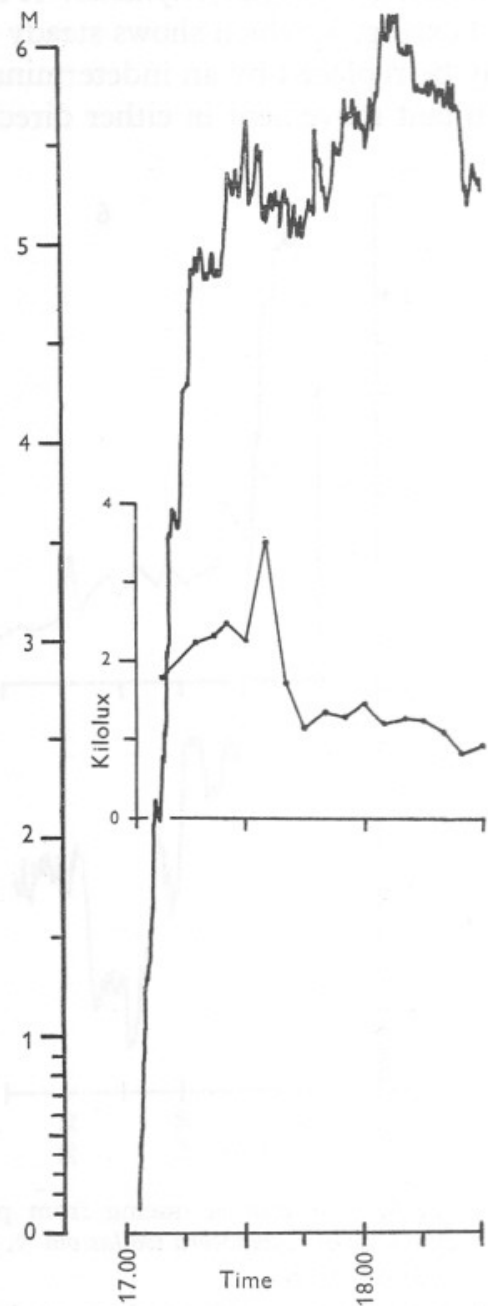

Text-fig. 8. Continuous tracing from part of record no. 24 showing the behaviour of a zoea larva, together with a graph of changes in light intensity (2I July I950).

may also swim horizontally into the sides of the tube. When they do this it is impossible to make a recording of them although of course, if they were in the sea, they would be moving horizontally or at a large angle to the vertical. 
Besides these large-scale movements of up-and-down or sideways swimming it is possible to detect by eye smaller-scale movements which are not recorded on the trace. Amongst the copepods it is clear that the steady and general type of propulsion involves the thoracic appendages and this forms the basis of the 'hop-and-sink' movement too. For short and much more rapid leaps, both violent movement of the antennae and flexing of the abdomen appear to be employed. Occasionally a violent caper may be indulged in when an animal leaps about in all directions with so great speed that it is not possible to determine which appendages are used.
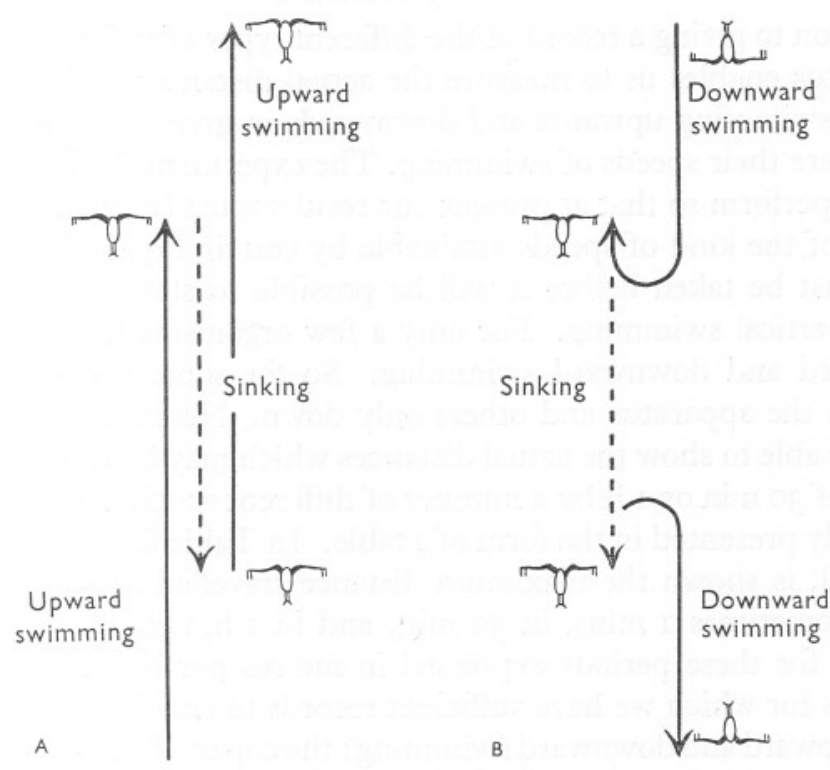

Text-fig. 9. Diagrams illustrating the two types of 'hop-and sink' behaviour of Calanus finmarchicus during (A) upward swimming, and (B) downward swimming.

The underwater observations reported in Bainbridge (I952, I953) were undertaken expressly to determine whether the swimming observed in apparatus of this type is similar to that occurring in the sea. The results reported make clear that it is so, and in general the observations made on animals in the wheel may be taken as applying also to behaviour in the sea. In particular the direct, the indirect, and the 'hop-and-sink' modes of up-and-down swimming have been observed in the sea, as has some amount of horizontal swimming and occasionally the violent caper mentioned above. The close parallel between all these movements in the wheel and in the sea makes it clear that reliance may be placed on the results and serves to refute the criticism that the 'canalizing' effect of the tube must make behaviour in the wheel unnatural. 
None of the animals which have been fitted into the above categories must be taken as moving solely in the manner described there. All the species mentioned have been observed to swim, at one time or another, in several or all of the ways described. Behaviour is both individualistic and variable. The account (p. 420) of the change in swimming of the medusa in the presence of Balanus nauplii serves to demonstrate both how swimming movements can be altered to suit particular circumstances and also how useful the wheel may be in making such observations.

\section{Speeds of swimming}

In addition to giving a record of the different types of swimming behaviour, the apparatus enables us to measure the actual distances various animals are capable of swimming upwards and downwards in given periods of time, and so to compare their speeds of swimming. The experiments take a long time to set up and perform so that at present our results must be regarded only as an indication of the kind of speeds attainable by certain organisms; many more records must be taken before it will be possible to state the limits to their speeds of vertical swimming. For only a few organisms have we records of both upward and downward swimming. So far some species would only swim up in the apparatus and others only down. Nevertheless, for the first time we are able to show the actual distances which may be travelled vertically in periods of $30 \mathrm{~min}$ or $\mathrm{I} \mathrm{h}$ by a number of different species. This information is most easily presented in the form of a table. In Table I, as far as possible for each animal, is shown the maximum distance travelled in a short period of $2 \mathrm{~min}$ (or sometimes I $\mathrm{min}$ ), in $30 \mathrm{~min}$, and in I h, together with the speed maintained for these periods expressed in metres per hour. There are only two animals for which we have sufficient records to enable us to compare the speeds of upward and downward swimming: the copepod Calanus finmarchicus and the euphausiacean Meganyctiphanes norvegica. For a short period of 2 min Calanus can swim upwards at a speed of $66 \mathrm{~m} / \mathrm{h}$ and downwards at $107 \mathrm{~m} / \mathrm{h}$; maintained for a whole hour the speeds are only 15 and $47 \mathrm{~m} / \mathrm{h}$ respectively. The copepod Centropages can climb $30 \mathrm{~m}$ in an hour. Meganyctiphanes can swim upwards at a speed $173 \mathrm{~m} / \mathrm{h}$ for $2 \mathrm{~min}$ and downwards at $215 \mathrm{~m} / \mathrm{h}$ for the same period; for a whole hour the respective speeds are 92.8 and $128.8 \mathrm{~m} / \mathrm{h}$. The remarkable speeds attained by so small a creature as a Balanus nauplius, as well as its powers of prolonged swimming, have already been commented on (p. 419).

\section{Differences between animals}

There are in general considerable differences in behaviour between animals which might be expected to react similarly. While the reaction-positive or negative-towards light may usually be uniform within a group of apparently identical animals caught at the same time, their speeds of swimming will differ 


\section{Table I. Distances Travelled and Speeds of Vertical Swimming of Various Plankton Animals over Different Periods of Time}

\begin{tabular}{|c|c|c|c|c|c|c|}
\hline & \multicolumn{3}{|c|}{ Up } & \multicolumn{3}{|c|}{ Down } \\
\hline & $\underset{(\mathrm{min})}{\text { Duration }}$ & $\begin{array}{l}\text { Distance } \\
(\mathrm{m})\end{array}$ & $\underset{(\mathrm{m} / \mathrm{h})}{\text { Speed }}$ & $\begin{array}{l}\text { Duration } \\
\text { (min) }\end{array}$ & $\begin{array}{l}\text { Distance } \\
\quad(\mathrm{m})\end{array}$ & $\begin{array}{l}\text { Speed } \\
(\mathrm{m} / \mathrm{h})\end{array}$ \\
\hline Calanus finmarchicus & $\begin{array}{r}2 \\
30 \\
60\end{array}$ & $\begin{array}{l}2 \cdot 2 \\
17 \cdot 8 \\
15\end{array}$ & $\begin{array}{l}66 \\
35^{\circ} 6 \\
15\end{array}$ & $\begin{array}{r}2 \\
30 \\
60\end{array}$ & $\begin{array}{l}3.57 \\
29.9 \\
47\end{array}$ & $\begin{array}{l}\text { I07 } \\
59 \cdot 8 \\
47\end{array}$ \\
\hline Euchaeta norvegica & = & 二 & 二 & $\begin{array}{r}2 \\
30 \\
60\end{array}$ & $\begin{array}{l}4 \cdot 52 \\
4 \mathrm{I} \cdot 25 \\
70 \cdot 4\end{array}$ & $\begin{array}{r}\text { I35.6 } \\
82.5 \\
70.4\end{array}$ \\
\hline Labidocera wollastoni & $\stackrel{2}{-}$ & $\stackrel{0.99}{-}$ & $\underline{29 \cdot 7}$ & $\begin{aligned} 2 \\
20\end{aligned}$ & $\begin{array}{l}0 \cdot 78 \\
7 \cdot 97\end{array}$ & $\begin{array}{l}23 \cdot 4 \\
23 \cdot 9\end{array}$ \\
\hline Centropages sp. & $\begin{array}{r}2 \\
30 \\
60\end{array}$ & $\begin{array}{l}I \cdot 82 \\
I 6 \cdot I \\
30 \cdot 6\end{array}$ & $\begin{array}{l}54 \cdot 6 \\
32 \cdot 2 \\
30 \cdot 6\end{array}$ & $\frac{2}{-}$ & $\frac{0.7}{-}$ & $\begin{array}{c}2 \mathrm{I} \cdot 0 \\
-\end{array}$ \\
\hline Temora longicornis & $\begin{array}{r}2 \\
30 \\
60\end{array}$ & $\begin{array}{l}0.63 \\
4.47 \\
5 \cdot 13\end{array}$ & $\begin{array}{c}18.9 \\
8.94 \\
5.13\end{array}$ & $\frac{2}{-}$ & $\frac{0.57}{-}$ & $\frac{\mathrm{I} 7 \cdot \mathrm{I}}{-}$ \\
\hline Paracalanus parvus & $\begin{array}{r}2 \\
30 \\
60\end{array}$ & $\begin{array}{l}I \cdot 09 \\
2 \cdot 14 \\
3 \cdot 24\end{array}$ & $\begin{array}{c}32 \cdot 7 \\
4 \cdot 28 \\
3 \cdot 24\end{array}$ & 二 & $=$ & E \\
\hline Acartia clausi & $\begin{array}{r}2 \\
30 \\
60\end{array}$ & $\begin{array}{l}\mathrm{I} \cdot \mathrm{I} 2 \\
4.43 \\
8.8 \mathrm{I}\end{array}$ & $\begin{array}{c}33.6 \\
8.86 \\
8.8 \mathrm{I}\end{array}$ & $\begin{array}{r}2 \\
8 \\
-\end{array}$ & $\begin{array}{l}0.57 \\
\mathrm{I} \cdot 6 \mathrm{I} \\
-\end{array}$ & $\begin{array}{l}\mathrm{I} 7 \cdot \mathrm{I} \\
\mathrm{I} 2 \cdot \mathrm{I} \\
-\end{array}$ \\
\hline Oithona similis & $\begin{array}{r}2 \\
30\end{array}$ & $\begin{array}{l}0.8 \\
3.96\end{array}$ & $\begin{array}{l}24 \cdot 0 \\
7 \cdot 92\end{array}$ & 二 & - & 二 \\
\hline Bopyrid larva & 二 & 二 & 二 & $\begin{array}{r}2 \\
30\end{array}$ & $\begin{array}{r}\text { I. } 75 \\
10.95\end{array}$ & $\begin{array}{l}52 \cdot 5 \\
21 \cdot 9\end{array}$ \\
\hline Calanus nauplius & $2 \cdot 5$ & 0.185 & $4 \cdot 44$ & 一 & - & - \\
\hline Balanus nauplius & $\begin{array}{r}2 \\
30 \\
60\end{array}$ & $\begin{array}{c}0.75 \\
7.63 \\
14.9\end{array}$ & $\begin{array}{l}22 \cdot 5 \\
15 \cdot 26 \\
14.9\end{array}$ & 二 & E & 二 \\
\hline Zoea (Brachyura) & $\begin{array}{r}\text { I } \\
2 \\
\text { IO }\end{array}$ & $\begin{array}{l}I \cdot I 7 \\
I \cdot 95 \\
4 \cdot 89\end{array}$ & $\begin{array}{l}70 \cdot 2 \\
58 \cdot 5 \\
29 \cdot 34\end{array}$ & 二 & E & E \\
\hline Meganyctiphanes norvegica & $\begin{array}{r}2 \\
30 \\
60\end{array}$ & $\begin{array}{l}5 \cdot 77 \\
62 \cdot 21 \\
92 \cdot 8\end{array}$ & $\begin{array}{r}\mathrm{I} 73 \cdot \mathrm{I} \\
\mathrm{I} 24.4 \\
92 \cdot 8\end{array}$ & $\begin{array}{r}2 \\
30 \\
60\end{array}$ & $\begin{array}{c}7 \cdot 17 \\
68 \cdot 2 \\
\mathrm{I} 28 \cdot 8\end{array}$ & $\begin{array}{l}215.1 \\
136.4 \\
128.8\end{array}$ \\
\hline Thysanoessa inermis & 二 & $\begin{array}{l}- \\
-\end{array}$ & 二 & $\begin{array}{r}2 \\
30 \\
60\end{array}$ & $\begin{array}{l}4.15 \\
19 \cdot 5 \\
40 \cdot 4\end{array}$ & $\begin{array}{r}\mathrm{I} 24 \cdot 5 \\
39^{\circ} 0 \\
40^{\circ} 4\end{array}$ \\
\hline Tomopteris & 二 & 二 & 二 & $\begin{array}{r}2 \\
28\end{array}$ & $\begin{array}{r}6 \cdot 84 \\
47 \cdot 46\end{array}$ & $\begin{array}{l}205 \cdot 2 \\
101 \cdot 7\end{array}$ \\
\hline $\begin{array}{l}\text { Sagitta elegans (small, } \\
\frac{1}{2} \text { in) }\end{array}$ & I & $\underline{0.44}$ & $\stackrel{26 \cdot 4}{-}$ & $\begin{array}{r}2 \\
15\end{array}$ & $\begin{array}{l}0.3 \\
\mathrm{I} \cdot \mathrm{I} 7\end{array}$ & $\begin{array}{l}9 \\
4 \cdot 68\end{array}$ \\
\hline Rossia macrosoma & 二 & - & 二 & $\begin{array}{r}2 \\
30\end{array}$ & $\begin{array}{r}4 \cdot 58 \\
44 \cdot 65\end{array}$ & $\begin{array}{r}137 \cdot 4 \\
89 \cdot 3\end{array}$ \\
\hline $\begin{array}{l}\text { Small medusa late Ephyra } \\
(\mathrm{I} \cdot 0 \mathrm{~cm} \text { diam.) }\end{array}$ & 二 & E & 二 & $\begin{array}{r}2 \\
30 \\
60\end{array}$ & $\begin{array}{l}\mathrm{r} \cdot 29 \\
\mathrm{I} \cdot 06 \\
27 \cdot \mathrm{I}\end{array}$ & $\begin{array}{l}38 \cdot 7 \\
30 \cdot 12 \\
27 \cdot 1\end{array}$ \\
\hline
\end{tabular}


greatly and one or two will even behave in the opposite manner. In four separate experiments with four similar Calanus females each caught at $10.30 \mathrm{~h}$ and experimented with at II.00 h on similar days, speeds for swimming down of $50.8,6.7,50.8$ and $13.5 \mathrm{~m} / \mathrm{h}$ were obtained. On another occasion, of two Calanus females caught at the surface at the same time, the first experimented with showed a somewhat uncertain, but slightly downward, movement from II. 52 to $20.45 \mathrm{~h}$, finally swimming down at $13.7 \mathrm{~m} / \mathrm{h}$ just before 20.45 ; the second, having been kept in a breffit during the day, was put in the wheel at

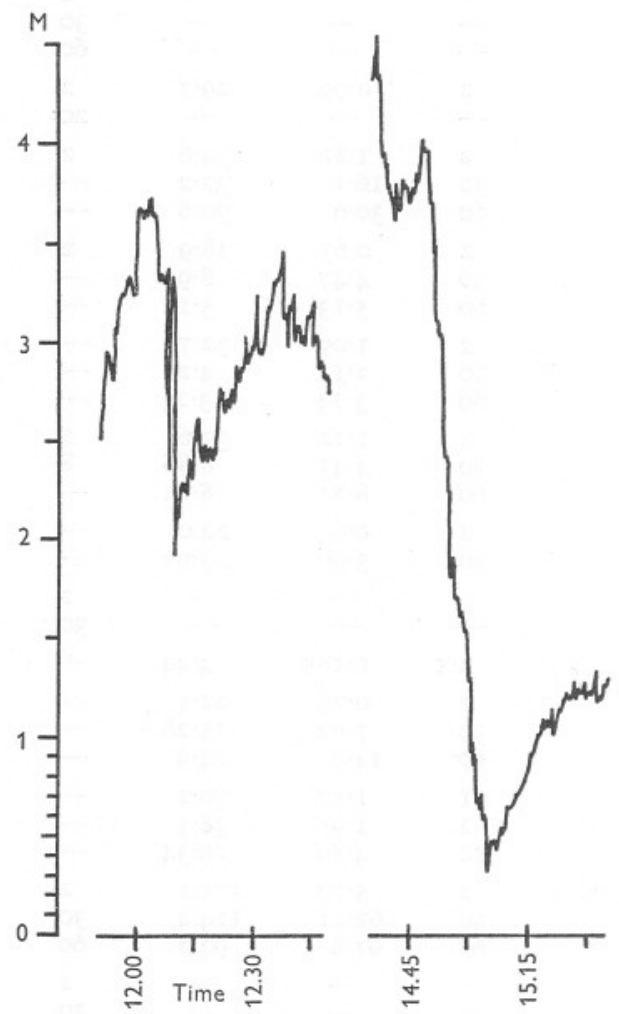

Text-fig. Io. Continuous tracings from kymograph record no. 46 showing the behaviour of Calanus in complete darkness (Io July 195r).

$20.55 \mathrm{~h}$ and swam up consistently at $18.6 \mathrm{~m} / \mathrm{h}$. Even the same animal may show differences under conditions which must be considered identical. Record no. 46 shows, in Text-fig. 1o, the swimming of a Calanus on two occasions separated by 2 hours. In one there is a slight upward resultant and in the other a downward one. At both times the greenhouse was completely blacked out. Record no. 43, which is discussed in the light intensity section (see Text-fig. 23 on p. 442), shows, further, how inconsistent the reaction of an 
individual (Cyclops) may be to some regulated stimulus such as partial blacking out.

This occurrence of variation where uniformity might be expected makes all the more difficult an interpretation of those cases in which differences might be expected. Three recordings were made with Calanus taken from the surface and from $60 \mathrm{~m}$. These were members of the spring brood which, in the Clyde

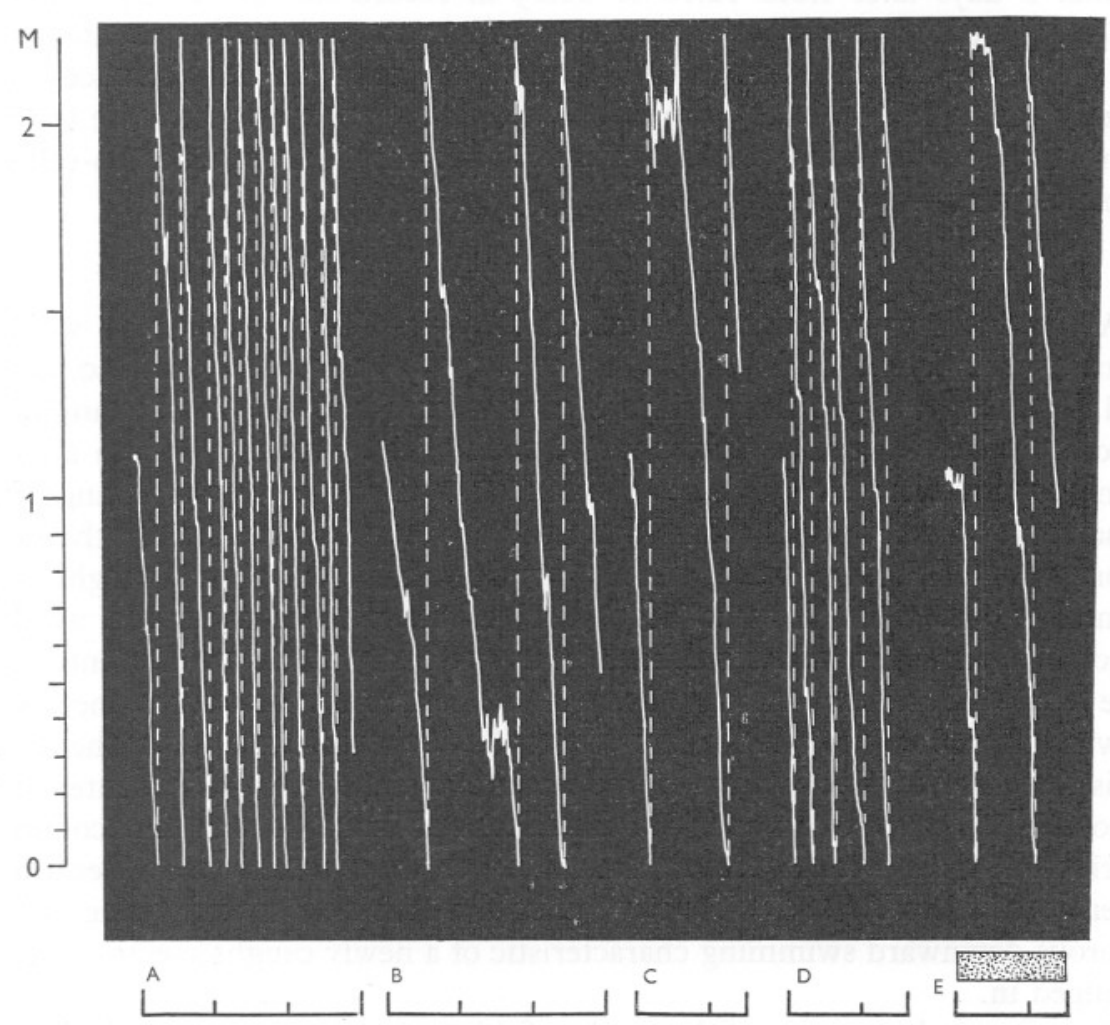

Text-fig. II. Reproduction of kymograph tracing from record no. 40. A, C. finmarchicus o $^{-}$

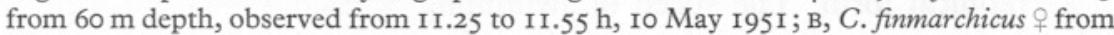
surface, observed from I2.I0 to I2.40 h, IO May I95I; C, same Calanus as in B but observed from II.40 to II.55 h on II May I95I; D, same Calanus as in A but observed from II.57 to I2.I2 h, II May I95I; and E, the same Calanus from I2.25 to I2.40 h. The stippled rectangle in E indicates partial blacking out of the greenhouse. The time scale is divided into Io min periods. See text below.

area, is often to be found partly or almost wholly up at the surface. In the first example, record no. 40 given in Text-fig. II, a Calanus male taken at $60 \mathrm{~m}$ swam down at $51.3 \mathrm{~m} / \mathrm{h}$ and in a second test at $39.1 \mathrm{~m} / \mathrm{h} ;$ a Calanus female taken at the surface also swam down but at 14.9 and $17.2 \mathrm{~m} / \mathrm{h}$ in separate tests. In a second example, not illustrated, a female from $60 \mathrm{~m}$ 
swam down at $\mathrm{I} \cdot 4 \mathrm{~m} / \mathrm{h}$ while one from the surface swam up at $35.6 \mathrm{~m} / \mathrm{h}$. In both these cases there is an understandable difference between the two types of animal, but in a third example the behaviour of stage $\mathrm{V}$ animals both from the surface and from $60 \mathrm{~m}$ was identical and consisted in swimming down at about $4 \mathrm{~m} / \mathrm{h}$. A further anomaly is revealed if the I2.IO-I2.40 period of swimming down in record no. 40 is compared with that of a precisely similar animal 2 days later from I2.IO to I2.25 in record no. 4I (p. 445); here a Calanus from the surface is found swimming up at $6 \mathrm{~m} / \mathrm{h}$. The light intensity on both these occasions was in the region of 6 kilolux. These differences are puzzling, but the possibility, suggested by Bainbridge (I952), must be borne in mind of there being no fundamental difference between the so-called 'surface' and 'deep' forms of Calanus.

\section{Changes in behaviour with time}

A series of experiments was performed with $C$. finmarchicus in which records were made each day for I h periods at II.30, I4.30, I7.30 and $20.30 \mathrm{~h}$, and also occasionally at intermediate times and later than $2 \mathrm{I} .30 \mathrm{~h}$. The animals used were caught immediately prior to testing and were taken from about $40 \mathrm{~m}$ depth. The aim of these experiments was to see if any change in behaviour occurred as the time for normal vertical migration in the sea approached. A change was generally clearly visible. When first caught the animals would swim down rapidly, but at later periods the speed would become less and less and sometimes an upward migration would eventually take place. There was much variation in the results but never was there an upward migration early in the day or a rapid downward one late in the day. This change of behaviour must be due either to the alteration in light intensity or to an alteration in the reaction of the animals rather than to their becoming moribund or adapted to the circumstances of their confinement, because, when it was possible to test the same animal on the next morning, the same vigorous downward swimming characteristic of a newly caught specimen was indulged in.

Text-fig. I2 shows some of the results of this series of observations depicted in a graphical form. The speed of swimming of each animal has been calculated for successive 5 min periods and expressed as $\mathrm{cm} / 5 \mathrm{~min}$. These values, termed positive if the animal was moving upwards, negative if downwards, are plotted with a scale representing time of day running horizontally. Those values pertaining to the same animal are joined by a distinctive line. Examination of this figure shows clearly the absence of upward migrations early in the day and the absence of marked downward ones late in the day.

It is clear that the typical daytime behaviour, under the light intensities experienced in the wheel, is a downward swimming, and such is shown in the early parts of a number of records, for example as shown in Text-fig. I3. (The upward swimming of the 'surface' Calanus mentioned elsewhere is of 


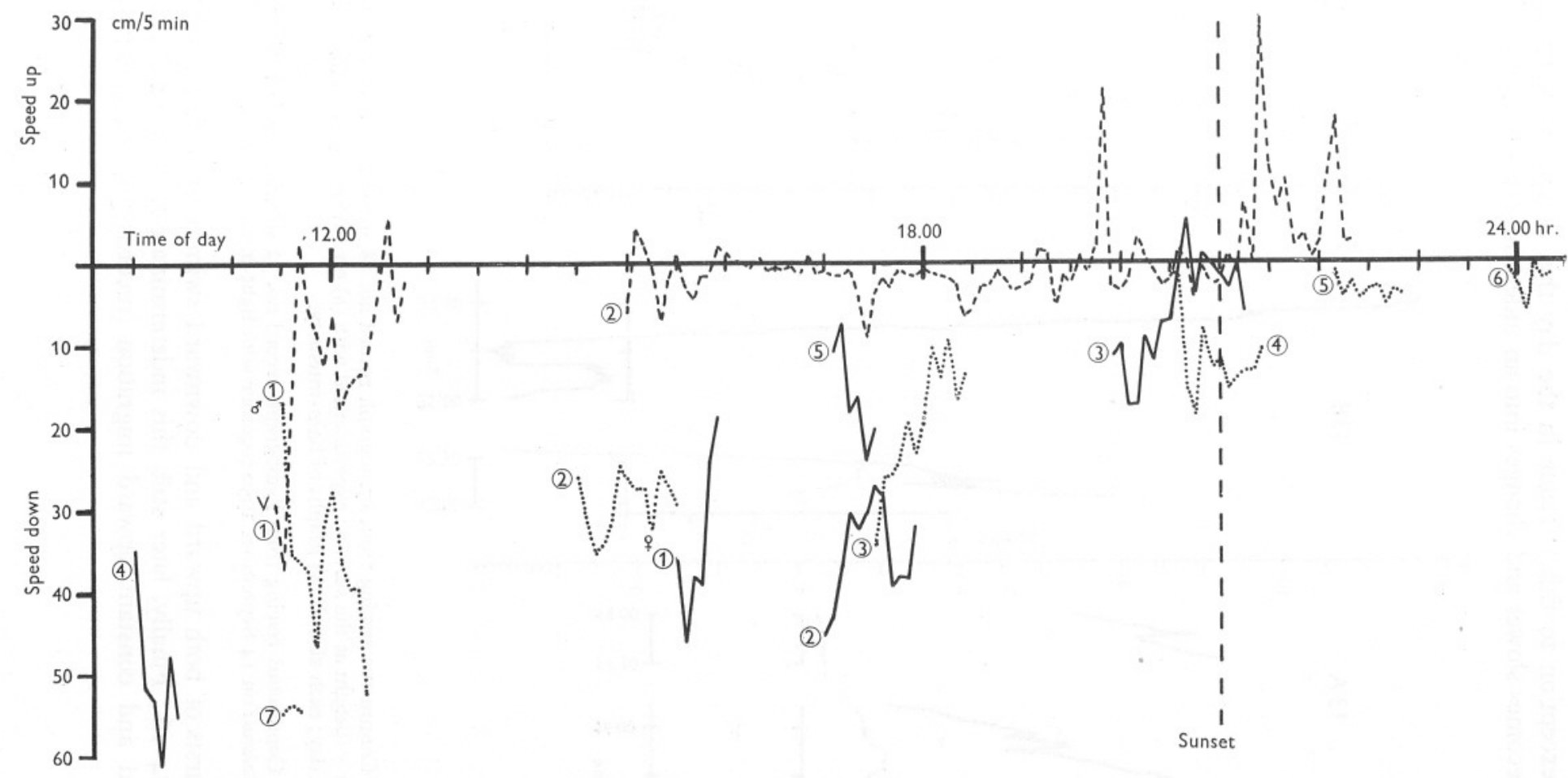

Text-fig. 12. Graph showing the variations in the speeds of swimming, either upwards or downwards, of three specimens of Calanus finmarchicus $(\hat{\sigma},+\circ$, and stage $\mathrm{V})$ at successive $5 \mathrm{~min}$ intervals during $\mathrm{I} 4 \mathrm{~h}$ periods. The order of making the recordings is shown by the figures in circles; $\sigma^{*}(7)$ and + (4) and (5) being taken on the day following the remainder of the records. 
course an exception to this.) Later in the day this downward movement generally becomes slower and changes into an indeterminate one comprising

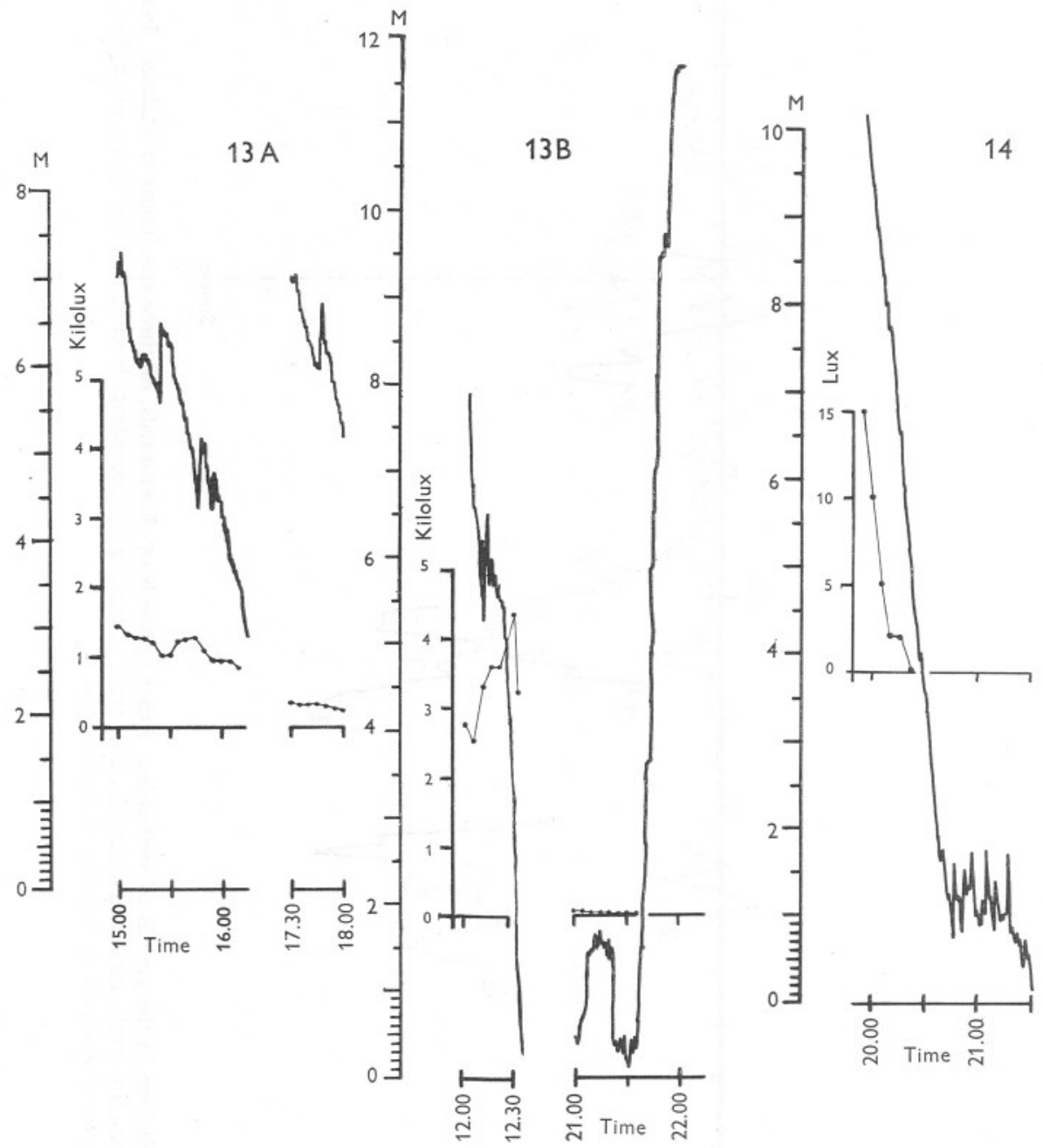

Text-fig. I3. Continuous tracing from kymograph record no. 38 showing the behaviour of a Calanus of (caught at the surface) experimented with (A) on 4 May I95I and (B) on the following day; each also shows graphs of light-intensity.

Text-fig. I4. Continuous tracing from kymograph record no. 32 showing the behaviour of Calanus on I4 September I950 together with light-intensity graph.

sporadic bursts of both upward and downward swimming, as is shown in Text-figs. I4-I6. Finally, later still, this indeterminate movement changes into a rapid and constant upward migration (records 38 , II, and 24 in 
Text-figs. I3, I7 and I8). This cycle is not always followed, however, as in no. 29 (Text-fig. I9), when an animal starts what might have been interpreted as the evening rise, only later (22.10 $\mathrm{h}$ ) to take to downward swimming again. The latter here can hardly be considered a midnight sinking for it is a definite swimming downward, not an irregular downward wandering. Records nos. 25 and 26 also show resumption of a rapid downward movement but, as would belexpected, on the following day.
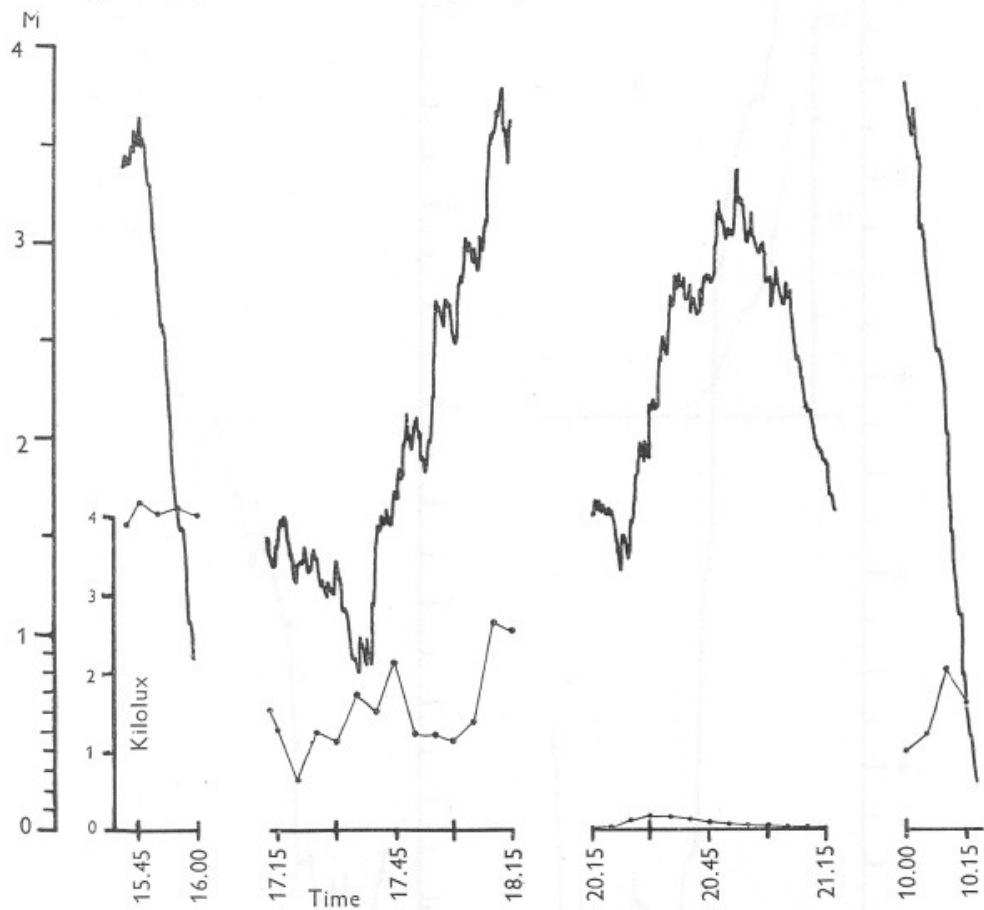

Text-fig. I5. Continuous tracing from kymograph record no. 36 showing the behaviour of Calanus of (caught at the surface) and experimented with on two consecutive days ( 2 and 3 May I95I), together with light-intensity graphs.

The evening migration in the sea is generally thought to begin about sundown, although of course we know nothing of the possible variation between individuals. In this respect it is interesting to consider the times at which upward swimming began in the various records we have obtained. Clear upward migrations in records nos. 24, 38 and II start respectively at 2 I.I5, 2I.30 and I6.05 h, while the abortive rise in no. 29 is at $2 \mathrm{I} .35 \mathrm{~h}$. Of these times $\mathrm{I} 6.05$ is well before sundown at the time of the experiment; 2I.I5 is Io min after; $2 \mathrm{I} .30, \mathrm{I} \mathrm{h}$; and $2 \mathrm{I} .35$, I h $20 \mathrm{~min}$ after. In no. 32 (Text-fig. I4) the downward migration changed to an indeterminate swimming at $20.45 \mathrm{~h}$, again I h $20 \mathrm{~min}$ after sundown. In record no. 36 (Textfig. I5) a similar change occurred at least at I7.15, although possibly earlier, 


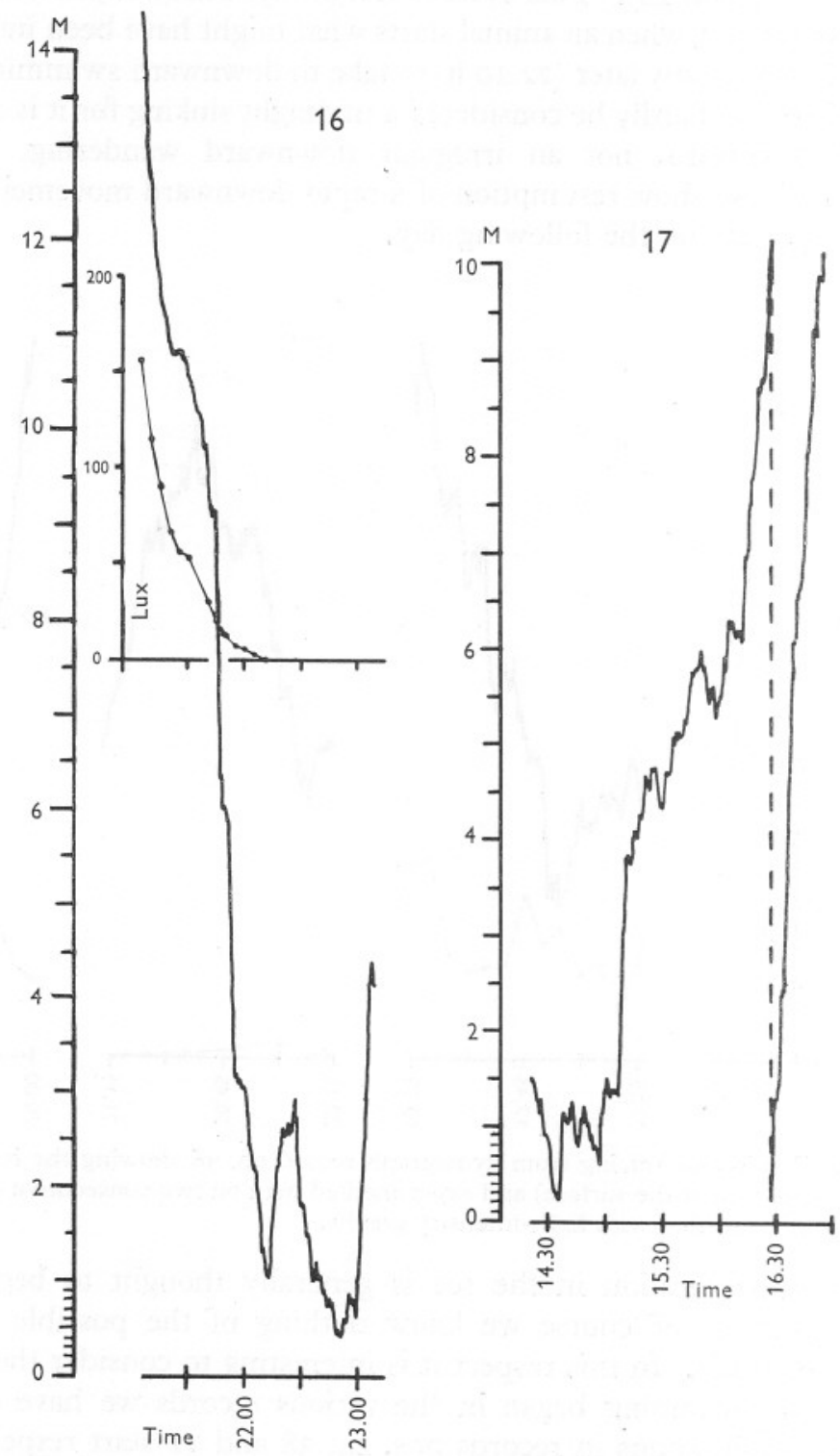

Text-fig. I6. Continuous tracing from kymograph record no. 27 showing the behaviour of Calanus, stage V, on 22 July 1950, together with light-intensity record.

Text-fig. 17. Continuous tracing from kymograph record no. II showing the behaviour of Calanus + on 15 June 1950. 
before the second part of the record began; but this particular Calanus was one of those found swimming near the surface.

Esterly (1917) gives evidence for the existence of a rhythm of upward migration, persisting even in continued darkness. It must therefore be considered whether those upward migrations obtained appear independent of the

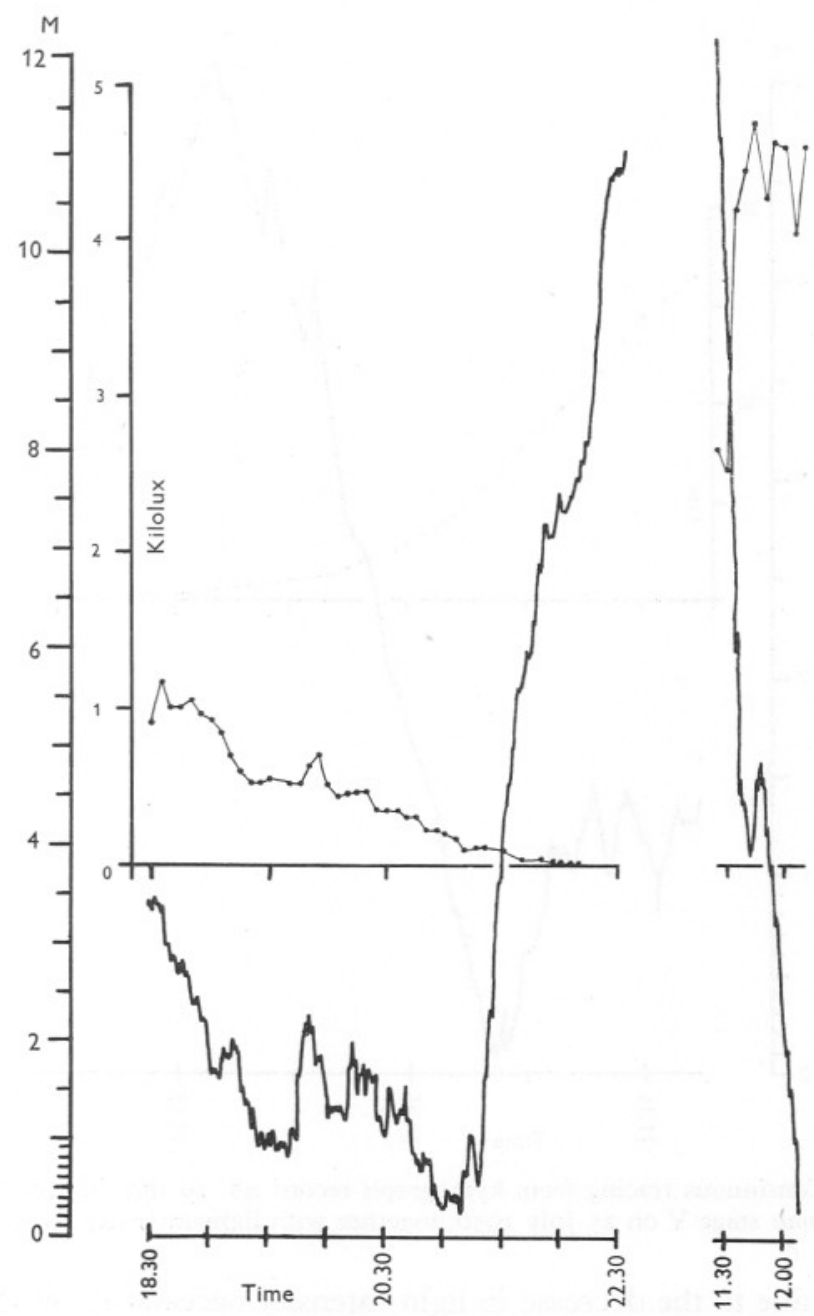

Text-fig. 18. Continuous tracings from kymograph records nos. 24 and 25 showing the behaviour of the same Calanus stage V on 2I July I950 and on the following morning, together with light-intensity records.

light intensity existing at the time or whether migration sets in at a particular intensity rather than at a particular time. In no. 24 (Text-fig. I8), upward movement starts when the light intensity has fallen to I 25 lux, in no. 29 
(Text-fig. 19) when it is at 60 lux and in no. 38 (Text-fig. I3) not until a zero reading was obtained. In no. 32 (Text-fig. I4) also, indeterminate movement set in at a zero intensity but in no. 36 there was no upward movement even at zero lux. It cannot be said how far all the changes of behaviour enumerated in this section may be due to the passage of time, and how far

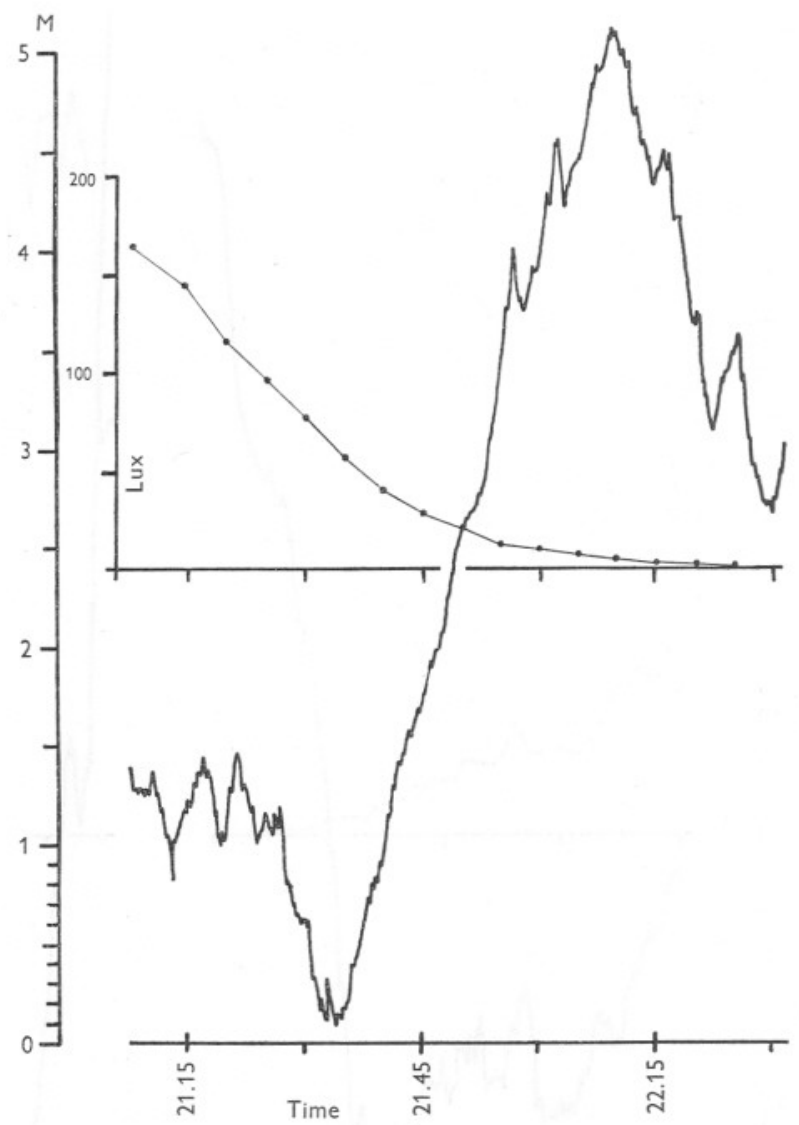

Text-fig. 19. Continuous tracing from kymograph record no. 29 showing the behaviour of Calanus stage V on 25 July 1950, together with light-intensity record.

they may be due to the decrease in light intensity necessarily associated with the advancing time of day. It seems possible, however, as upward migrations could not be induced by blacking out during the daytime, that there may be a rhythm in the capacity to respond to a great reduction in light intensity. This would account for the lateness of those migrations that were obtained, as the intensity just below the surface must reach that equivalent to the sundown intensity at 50 or $60 \mathrm{~m}$ depth, much later in time. 
It is known from other experiments that the behaviour of Calanus, in particular, changes with prolonged captivity. This was again found to be so and a greater proportion of animals swimming up was always found amongst samples that had been obtained several days previously. For this reason animals were experimented with as soon as possible after the time of capture.

\section{Correlation of behaviour with changes in light intensity}

It has for a long time been considered, and indeed from time to time clearly demonstrated, that the vertical migrational behaviour of plankton animals is in part influenced by changes in light intensity. As already explained (p. 4I5) the wheel apparatus was mounted in a greenhouse whose sides were covered with layers of tissue paper to represent a dome of light, brightest above and falling off at the sides, similar to conditions in the sea; then the actual intensity of the overhead light could be varied from full daylight to complete darkness by drawing over more and more sheets ranging from white, through grey to black. This latter process, however, cannot be made as gradual as the changes in light intensity experienced by the animals in the sea. As also explained, for the majority of records, readings of light intensity were obtained by a photo-cell and sensitive galvanometer (see p. 4I5). We were thus able to obtain many records of the behaviour of individual animals under known conditions of illumination.

First we will consider seven records for which we have no light intensity readings but during which the light was varied from daylight to complete darkness as explained above. Record no. I, illustrated in Text-fig. 3 (p. 4I8), has already been discussed as an example of the method on p. 4I9, and here we noted that the gradual blacking out to complete darkness and return to daylight had no apparent effect on the behaviour of the Calanus then used.

Record no. 9 (not reproduced here) showed, in the first part, a large Meganyctiphanes norvegica, observed in the wheel from II. 38 to I $2.45 \mathrm{~h}$; it was swimming down rapidly and slightly increasing its speed as the light began to be reduced. As soon as complete darkness was reached the descent was checked and then, after some up-and-down movement, continued but at a slower rate and with a number of pauses. A new part of the record was started at 14.42 with another specimen of $M$. norvegica; one of medium size. This time the record started in complete darkness and the animal began by making almost as rapid a descent as did the other specimen in full daylight, but after about 15 min its behaviour changed, its descent being broken by many short up-and-down movements. When full light was restored it descended again but less rapidly than in the dark, and it was seen to pause for a time at regular intervals which, from their distance apart, must have corresponded to the position of the doors at the junctions between the sections of the wheel; although transparent they may produce a slight shadow. 
In no. 3 I (also not reproduced), Calanus finmarchicus began by descending, then went up for a short distance and then down more steeply. Descent now continued till the end of the record at $\mathrm{I} 6.00 \mathrm{~h}$, but during the period in which the light was reduced-either to a partial blackout or to complete darknessthe speed of descent was also reduced; on full daylight being restored again the speed of descent increased once more.

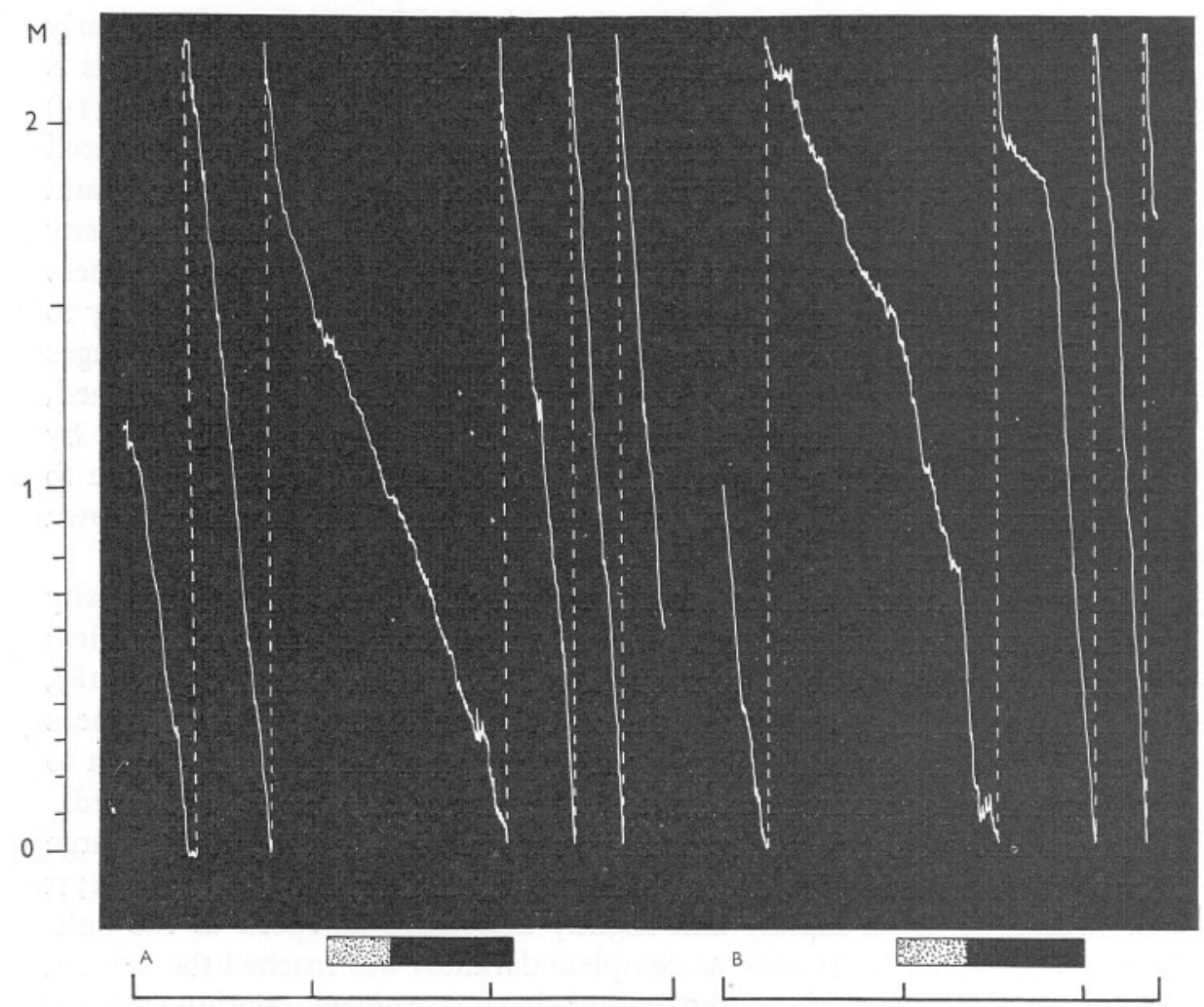

Text-fig. 20. Reproduction of kymograph tracing from record no. 42. A, behaviour of a specimen of Cypris sp. observed from I6.35 to I7.05 h on I5 May I95I. B, the same specimen from 10.20 to $10.45 \mathrm{~h}$ on I6 May I95I. The stippled and blackened rectangles indicate respectively periods of partial shading and complete darkness. The time scale is divided into ro min periods. See text below.

Text-fig. 20 shows record no. 42 which follows the descent of a freshwater Cypris (species undetermined). Here the recording paper is moving at $5 \mathrm{~mm}$ per min. The first part, made from I6.35 to $\mathrm{I} 7.05 \mathrm{~h}$ on I5 May I95I, shows a similar reduction in the speed of downward movement during the partial and complete blackout, as observed in the previous record for Calanus; the second part, however, 10.20-10.45 h on the following day, shows a reduction 
of speed before the blackout and an increase in speed again before the daylight was restored.

No. 43, made also on I6 May I95I, shows in Text-fig. 2I the varying behaviour of freshwater Cyclops. The first part is with a male from 12.25 to $\mathrm{I} 2.45 \mathrm{~h}$, and each time a partial blackout is introduced the downward swimming is at once changed to an upward movement; on the first occasion the

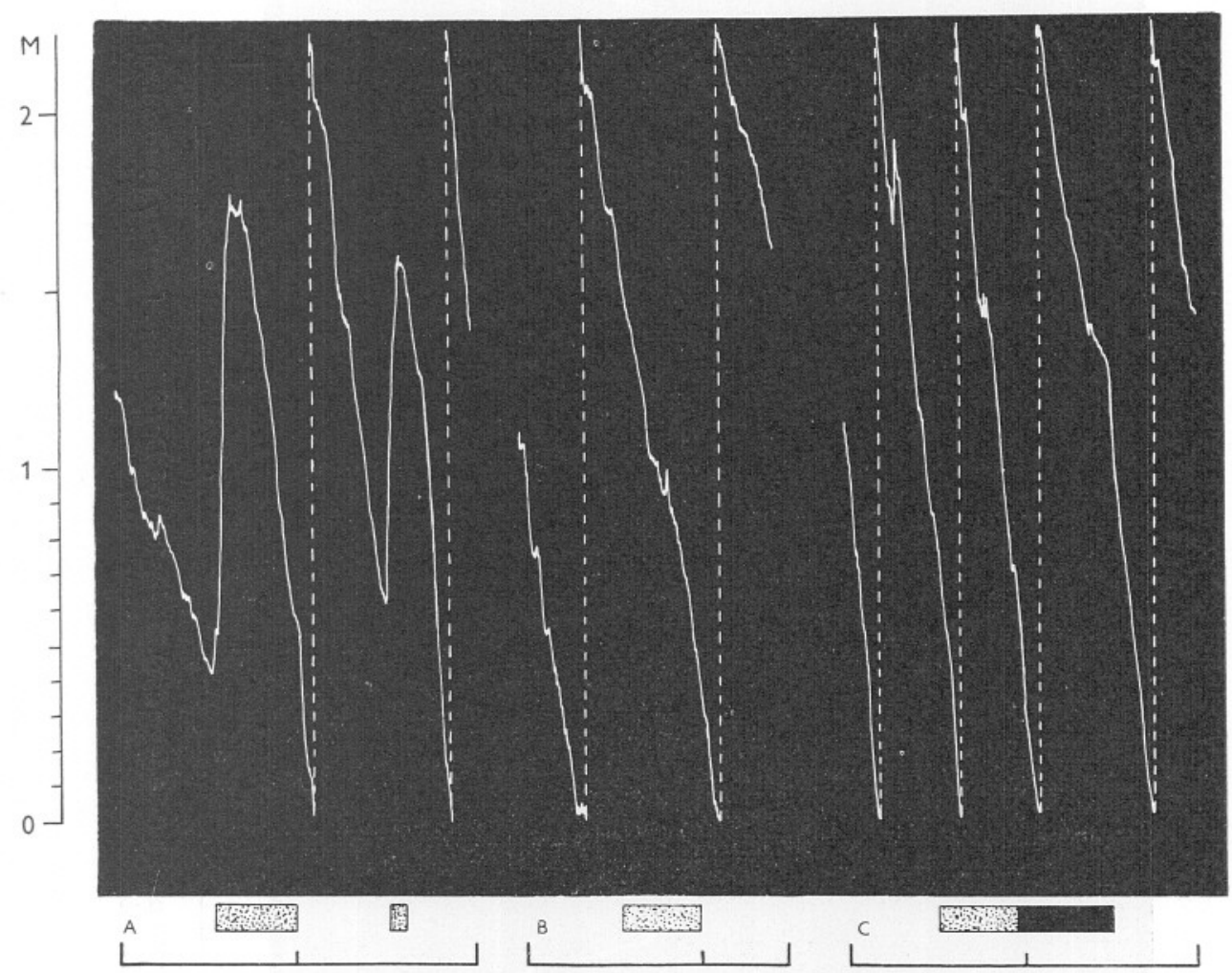

Text-fig. 21. Kymograph tracing from record no. 43. A, behaviour of Cyclops sp. $\hat{\sigma}$ from I2.25 to I2.45 h on I6 May I95I; B, Cyclops sp. + from I5.Io to I5.25 h on I6 May I95I; C, same as in A from I5.25 to I5.45 h also I6 May I95I. The stippled and blackened rectangles indicate respectively periods of partial shading and complete darkness. The time scale is divided into ro min periods. See adjacent text.

animal swims up $\mathrm{I} \cdot 35 \mathrm{~m}$ and then begins to descend again, although the partial blackout is still maintained, while the next time the full light is restored before the animal has climbed more than I $\mathrm{m}$ and it descends again as soon as the light increases. The second part of the record is made from I5.IO to I5.25 h with a female Cyclops, but here the partial blackout appears to have no effect upon its downward movement. In the third part, I 5.25-I 5.45, the same male as 


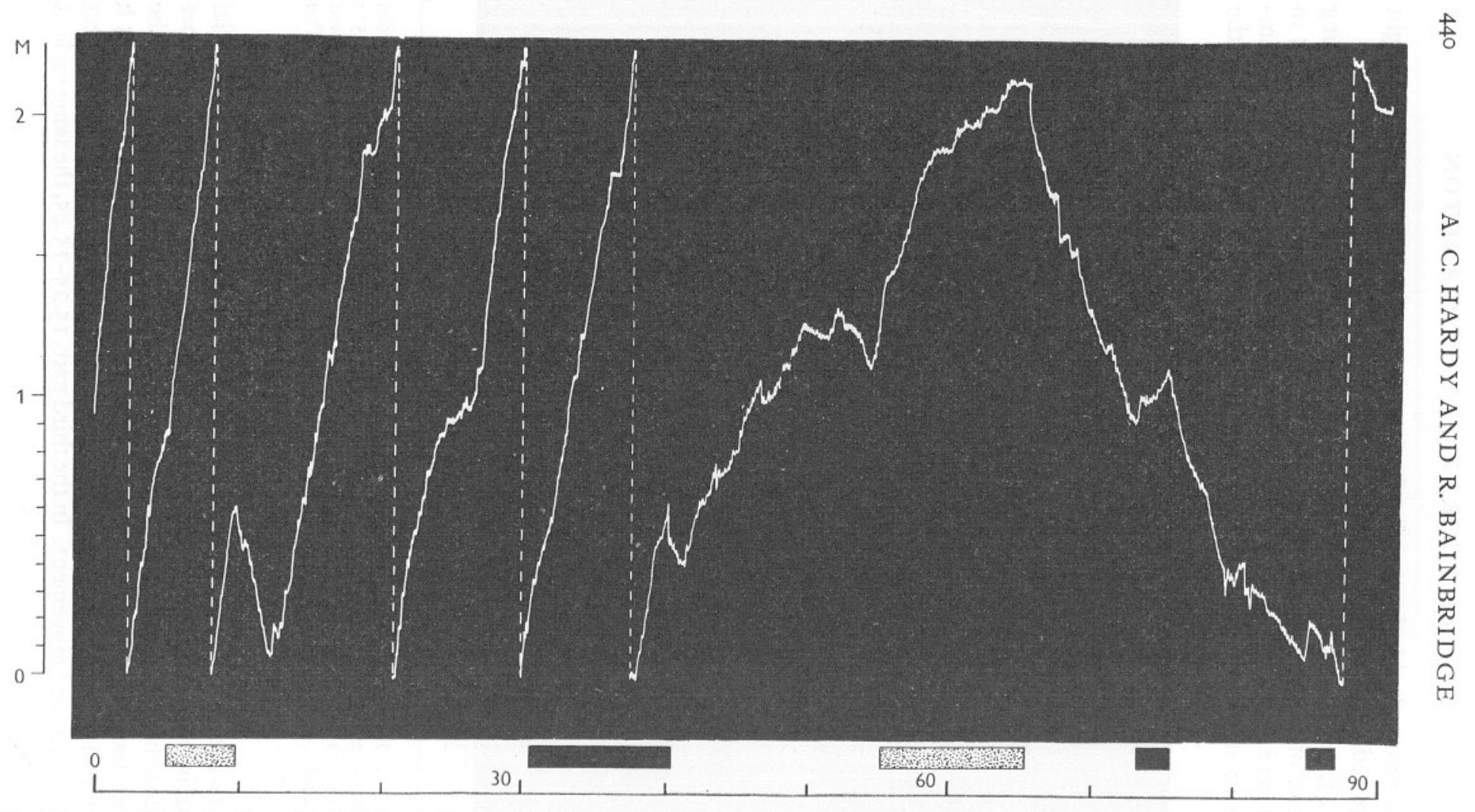

Text-fig. 22. Kymograph tracing from' record no. 44 (I6 May 195I). Behaviour of Daphnia sp. from 17.10 to I8.40 h. Stippled and blackened rectangles indicate respectively periods of partial shading and complete darkness. The time scale is divided into ro min periods. See text opposite. 
was used in the first part is again subjected to a partial blackout which is then followed by complete darkness; this time its behaviour appears quite unaffected.

No. 44 shows the behaviour of Daphnia species from I7.IO to I8.40 h with the light reduced or completely cut off for short periods as indicated below the graph in Text-fig. 22. The changes in light intensity have only a limited effect upon its general movement, which is upward for just over $\mathrm{I} h$ and then downward. After the first partial blackout there is a short period of downward swimming immediately the full light is restored, similarly for a shorter period after the first full blackout. Just before the second partial blackout there is an indication that the animal was beginning to descend, but it ance swims quickly upward for a short time as soon as the light is reduced, then after a slackening in climbing it begins its main descent when the light increases again. Its descent, however, is checked and changed to an upward movement at a second complete blackout, and is checked again but not so effectively at the third and last short period of darkness. A further experiment with Daphnia is shown in Text-fig. 28 and discussed on p. 443.

Record 47 (Text-fig. 23) shows the movement of a Calanus o for $23 \mathrm{~min}$ in complete darkness, I4.37 to I5.00 on I3 July I95I, when it rises and falls, rises and falls; then in a second 20 min period when full light is restored after Io min the same animal makes a continuous and rapid descent of some II $\mathrm{m}$.

Before passing to the records accompanied by actual light-intensity measurements reference should be made to record no. I7 where the behaviour of a Calanus female is recorded on 22 June I950 in three parts: II.44-I2.44 h with 'heavy cloud and no sun', I4.35-15.35 h with 'some cloud and strong sun' and I7.30-I8.30 h 'some cloud but little sun'. It is shown in Text-fig. 24, having been retraced on a reduced scale to give a more continuous graph. Here the speed of descent appears to show some correlation with light. In the first hour, about midday, during which there is heavy cloud and no sun, it descends only $6 \mathrm{~m}$; in the last hour, towards evening, but when there is a little sun, it descends $8 \mathrm{~m}$; whereas in the full afternoon with strong sun it descends nearly $23 \mathrm{~m}$.

The remaining figures in this section have all been retraced from those kymograph records accompanied by light-intensity measurements; the latter are shown with them. Record no. 26 in Text-fig. 25, from I5.00 to I8.30 on 22 July, shows Calanus stage $\mathrm{V}$ descending and subjected to a complete blackout; its speed of descent is appreciably reduced during darkness and greatly increased again as soon as light is restored. Text-figs. no. 26 and 6 (pp. 443 and 423) are parts of the same record, no. 28, taken on 25 July I950; the first part from I7.20 to I8.20 h recording Calanus stage V and the second part 18.30 to $2 \mathrm{I} .00 \mathrm{~h}$ recording Labidocera wollastoni ${ }^{\mathrm{s}}$. In the second part the light intensity is a good deal lower than in the first part and is shown on a different scale. In each case as the light declines so the downward movement of the animal is checked. 
Text-fig. 27 shows the behaviour of a Calanus stage V in record no. 37, from I4.00 to I6.30 and I7.00 to I7.30 h on 3 May I95I, and from Io.00 to I0.50 $\mathrm{h}$ on the following day. In the first period it begins by climbing some

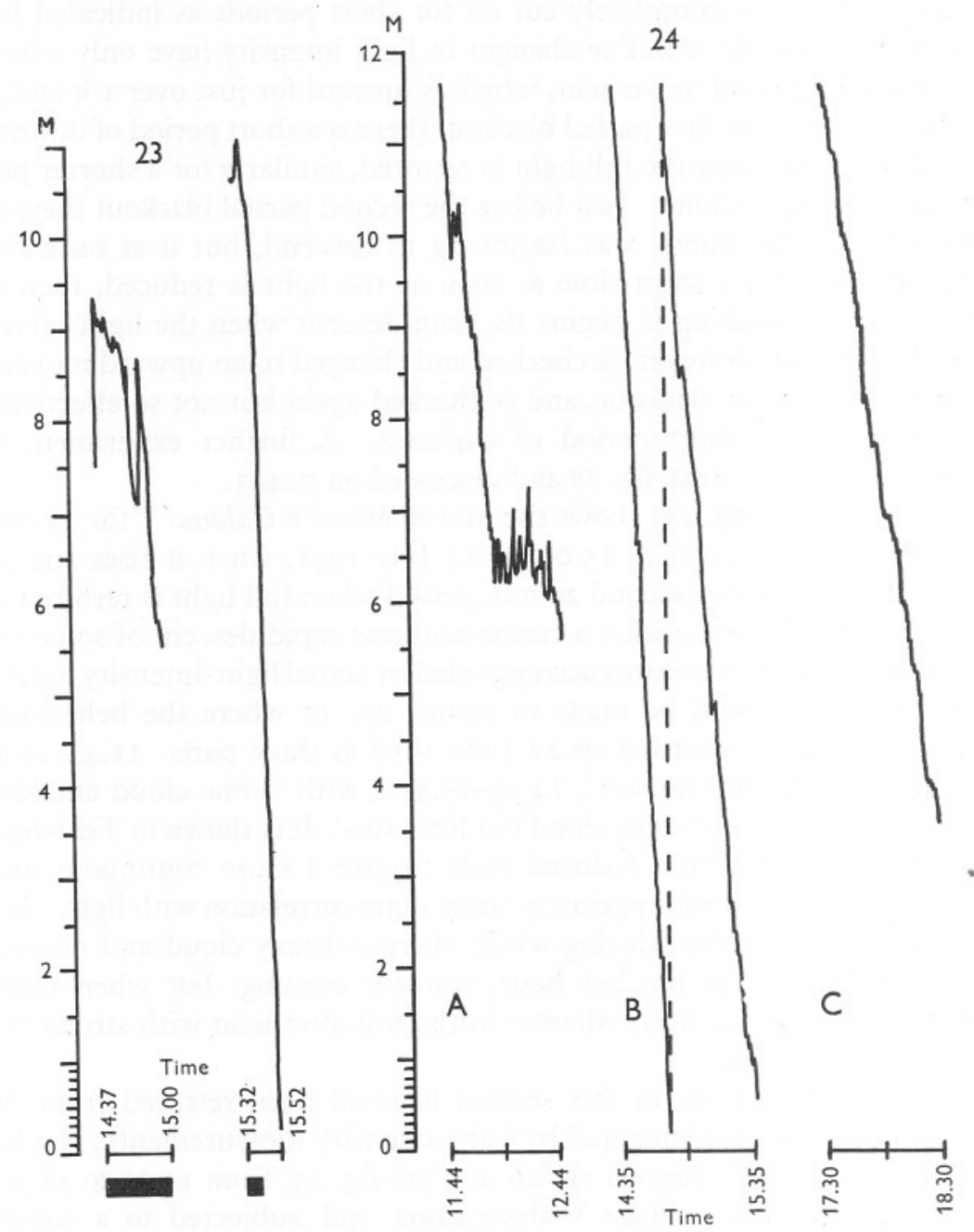

Text-fig. 23. Continuous tracing from kymograph record no. 47 (I3 July I95I) showing behaviour of Calanus ㅇ with artificial blackout.

Text-fig. 24. Continuous tracing from kymograph record no. I7 (22 June 1950) showing the behaviour of Calanus $q$ under different conditions of cloud and sunlight (see text, p. 44I): A, heavy cloud, no sun; B, some cloud, strong sun; c, some cloud, little sun.

$9 \mathrm{~m}$ and then makes an equally rapid descent of $\mathrm{I} 8 \mathrm{~m}$ when there is a check for half an hour followed by a further rapid descent; its movement shows no correlation at all with the light intensity which falls from 5.6 to 4 kilolux with 
fluctuations due to passing clouds. It is likewise impossible to see any obvious correlation in the other two periods.

Text-fig. 28 shows record no. 39 made with Daphnia sp. on 7 May I95I. In the first period of half an hour the light is raised from 4 to 8 kilolux and then down to darkness; in the second period of half an hour it is raised from darkness to 6 kilolux and back to darkness again, but on neither occasion does the downward movement of the animal appear to be affected. In the
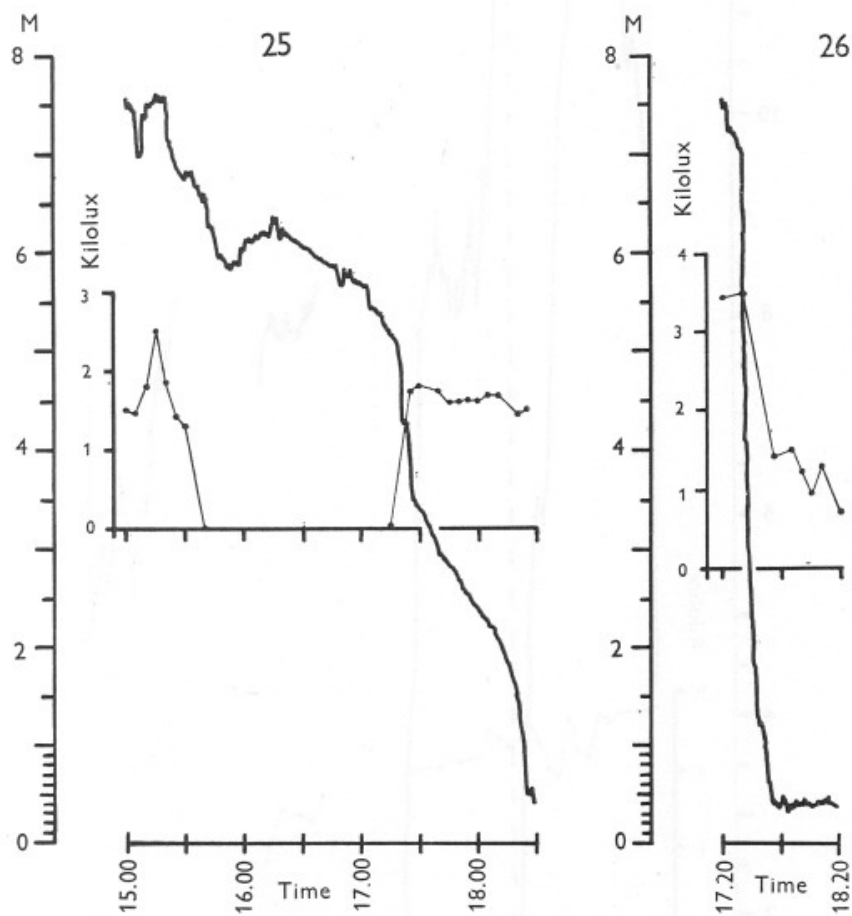

Text-fig. 25. Continuous tracing from kymograph record no. 26 (22 July I950) showing the behaviour of Calanus stage V with artificially produced blackout as shown in lightintensity graph.

Text-fig. 26. Continuous tracing from part of kymograph record no. 28 (25 July I950) showing the behaviour of Calanus stage $\mathrm{V}$ with decreasing light intensity as shown in accompanying graph.

third period, however, from I4.45 to I6.IO, the behaviour of the same animal is markedly different; as soon as the light falls from 6 kilolux to zero the Daphnia climbs for some $6 \mathrm{~m}$ and then, when the light is brought back to 6 kilolux, it descends as steeply for nearly $15 \mathrm{~m}$ only to start climbing again as the light is again dimmed; finally it falls yet again as the light is once more increased. 
Record no. 4I, illustrated in Text-fig. 29, is particularly interesting because it is made with one of the spring brood of Calanus, a female taken at the

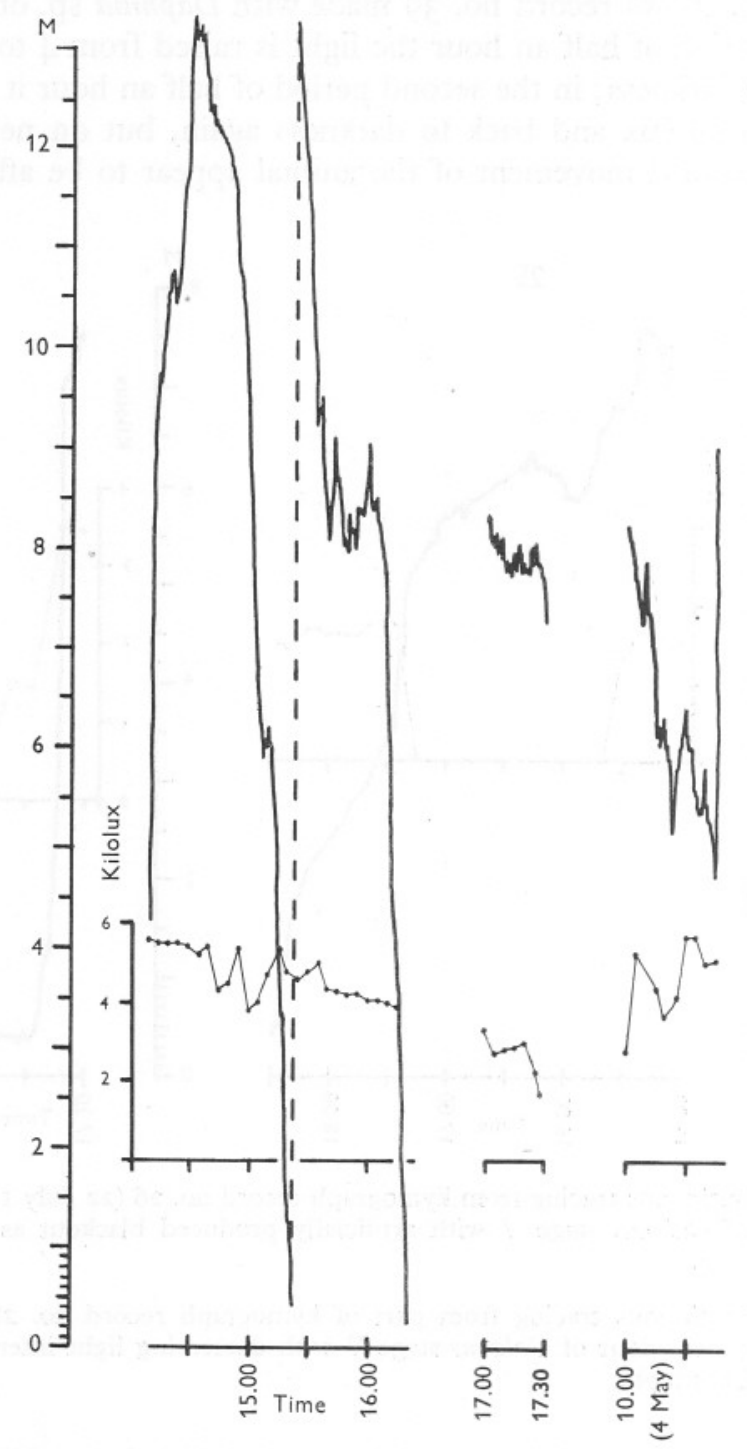

Text-fig. 27. Continuous tracing from kymograph record no. 37 ( 3 and 4 May I95I) of Calanus stage $\mathrm{V}$ showing behaviour which appears to have no correlation with accompanying light-intensity graph.

surface in bright light at Millport on I2 May 1951. The record is from I2.IO to I2.5O with a $5 \mathrm{~min}$ break at $\mathrm{I2.25}$. The animal starts by climbing steeply while the light is increased from 5.6 to 7.5 kilolux and continues to 

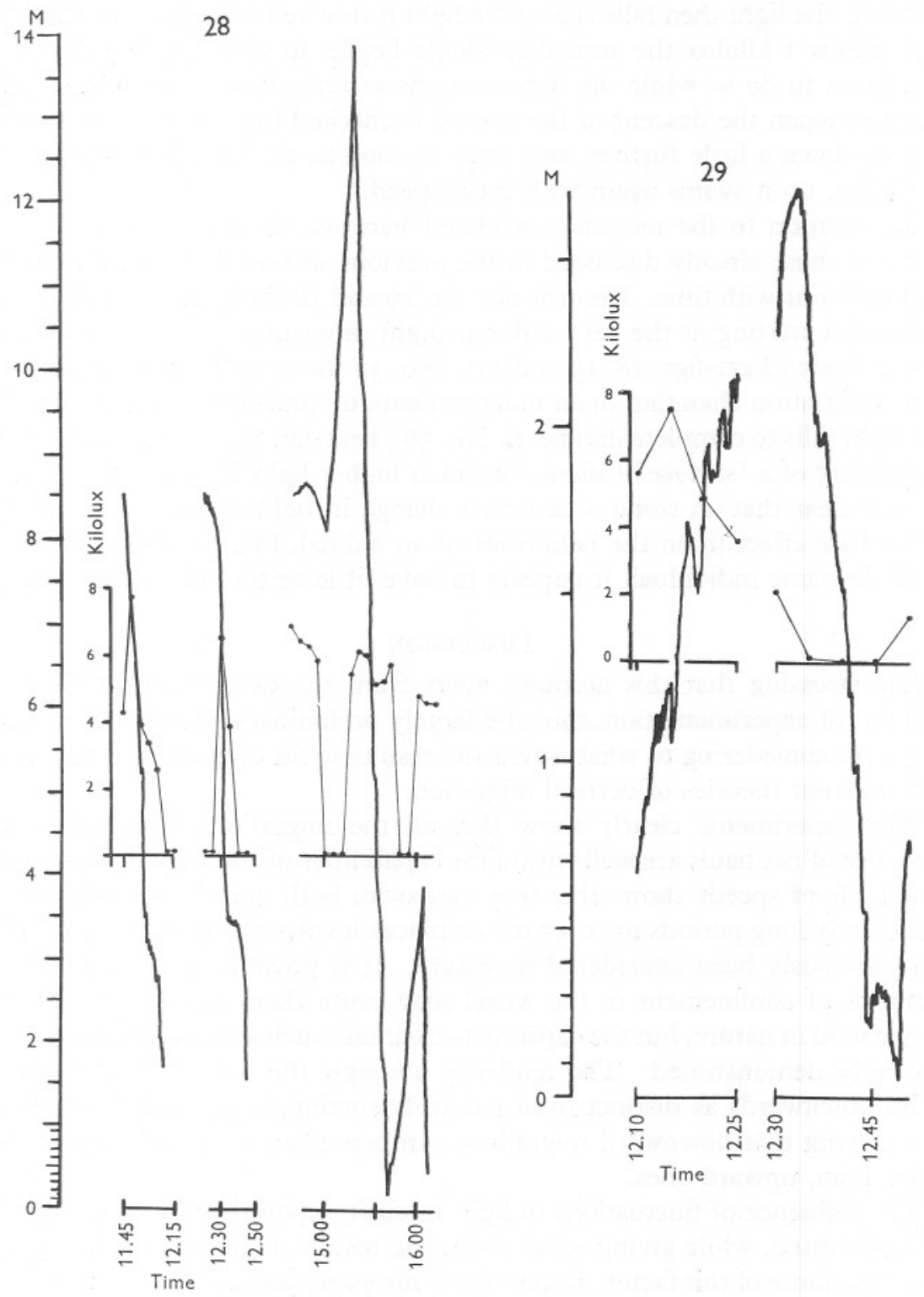

Text-fig. 28. Continuous tracing from kymograph record no. 39 (7 May I95I) showing the behaviour of Daphnia sp. under artificial control of light as shown in light-intensity graph. See text, p. 443 .

Text-fig. 29. Continuous tracing from kymograph record no, 4I (I2 May I95I) showing the behaviour of Calanus + caught at the surface and placed under artificially controlled light as shown in accompanying graph. See text, p. 444 . 
climb as the light then falls again; the light is now reduced gradually and as it falls below I kilolux the animal suddenly begins to swim rapidly down and continues to do so while the light remains at zero. When the light starts to increase again the descent of the animal is checked for a few minutes before it goes down a little further, and then, as soon as the light intensity reaches I kilolux, up it swims again with great speed.

In addition to the records considered here we should also refer back to some of those already discussed in the previous section dealing with changes of behaviour with time. Records nos. 24, 29 and 38 show an upward evening migration starting at the very different light intensities of I25, 60 and o lux respectively (Text-figs. I8, I9 and I3). No. 32 shows in Text-fig. I4 a downward migration changing to an indeterminate up-and-down movement when the light falls to complete darkness. No. 36 (Text-fig. I5) shows some upward swimming of a 'surface' Calanus at much higher light intensities.

It is clear that on some occasions a change in light intensity will have an immediate effect upon the behaviour of an animal, but at other times, even with the same individual, it appears to have little or no influence at all.

\section{Discussion}

While stressing that this account, apart from the description of this new method of experimentation, must be largely preliminary, it may nevertheless be worth considering to what extent the results so far obtained are consonant with current theories of vertical migration.

The experiments clearly show that all the migrations reported on the evidence of net hauls are well within the capabilities of the animals concerned. The table of speeds shows that they can swim both quickly enough and for sufficiently long periods to cover the distances involved in even less time than has previously been considered necessary. It is possible of course that the stimulus of confinement in the wheel may cause them to swim faster than they would in nature, but the capacity to maintain such speeds for long periods is clearly demonstrated. The tendency amongst the forms investigated, to swim downwards as distinct from passively sinking, is especially interesting in verifying that downward migrations can take place as quickly as, or even faster than, upward ones.

The influence of fluctuations in light intensity upon the movements of the animals tested, while giving some confusing results, is further evidence as to the importance of this factor. Except for Centropages (and specimens of Calanus finmarchicus found at the surface in daylight during the spring), all the animals tested exhibited a negative reaction towards strong light and swam downwards and away from it at some of the highest speeds. A gradual reduction in intensity is usually accompanied by a diminution in this reaction and at low values in the evening it may be replaced by a migration upwards and towards the light. The artificial removal of all light during the daytime 
does not on most occasions evoke an upward movement, and so it is clea $r$ that there is not a negative geotaxis which comes into play in the absence of the inhibiting effect of strong light; there is clearly demonstrated, again on most but not on all occasions, a definite positive migration towards the source of low light intensities. If these latter reactions should occur in the sea then most animals, if they were reacting in the same way, would automatically accumulate in regions of a certain light intensity (which may conveniently be termed the optimum) and move up to the surface as the level of this intensity rises with the setting sun; this indeed is as postulated in the hypotheses of Michael (I9II) and Russell (I926). The movement towards the optimum conditions is shown generally not to be a random or 'indirect' one but, in most of the larger forms, to consist of sustained directional swimming either up or down; this appears to be replaced by a 'hop-and-sink' type of movement when the region of optimum conditions has been reached.

This simple picture of daily change is not always true, however, and sometimes (as with the upward swimming of some of the surface members of the spring brood of Calanus) it may be completely reversed. Centropages exhibited this reverse type of behaviour whenever we observed it, and the effect of this in the sea would be to keep individuals near the surface during the hours of daylight. Even apart from these regular exceptions, however, the variation met with among the different animals experimented with shows that their migrations cannot be governed by changes in light intensity alone. In record no. 43 (p. 439), for example, we have seen that a partial blackout at midday caused a Cyclops male to swim upwards at once, whereas in the afternoon of the same day both a partial and a complete blackout had no effect whatever on the same individual. Similarly, with Daphnia in record no. 39 (Text-fig. 28, p. 445) marked alterations in light intensity in the morning on this occasion had no effect on its behaviour, whereas in the afternoon a complete blackout caused the same individual to swim rapidly upwards on two occasions. These results clearly show that a great many more observations are required before we can determine the relative importance of light and other factors in the regulation of vertical migrational behaviour.

\section{SUMMARY}

An apparatus is described in which it is possible to observe and make continuous records of the vertical migrations of plankton animals, if necessary through hundreds of metres of water.

Records obtained with this apparatus are described and discussed.

It is considered that vertical migration in the sea is predominantly a direct up-and-down swimming with only a few smaller forms moving in an indirect way. Downward migration is shown to be an active swimming and not a passive sinking. 
The speeds of vertical swimming of various animals are measured and listed.

Much variation and 'individuality' is shown amongst the animals studied but a pattern of behaviour consisting of a rapid movement downwards and away from the bright light during the day, followed by a diminution of this as the light intensity falls and an eventual movement upwards under low light intensities, appears to be usual. Upward migration cannot generally be induced by blacking out during the daytime and is assumed to be a positive migration towards low light intensities rather than a negative geotaxis.

\section{REFERENCES}

BAINBRIDGE, R., I952. Underwater observations on the swimming of marine zooplankton. F. Mar. biol. Ass. U.K., Vol. 31, pp. 107-I2.

- 1953. Studies on the interrelationships of zooplankton and phytoplankton. F. Mar. biol. Ass. U.K., Vol. 32, pp. 385-447.

Cushing, D. H., I95I. The vertical migration of planktonic Crustacea. Biol. Rev., Vol. 26, pp. 158-92.

ESTERLY, C. O., I9I7. Specificity in behaviour and the relation between habits in nature and reactions in the laboratory. Univ. Calif. Publ. Zool., Vol. I6, pp. 38I-92.

HARDY, A. C. \& BAINBRIDGE, R., I95I $a$. Effect of pressure on the behaviour of decapod larvae (Crustacea). Nature, Lond., Vol. I67, p. 354.

- I95 $\mathrm{I} b$. Vertical migration of plankton animals. Nature, Lond., Vol. I68, pp. 327-8 (substance of a paper read at the British Association).

Hardy, A. C. \& Paton, W. N., 1947. Experiments on the vertical migration of plankton animals. F. Mar. biol. Ass. U.K., Vol. 26, pp. 467-526.

MiCHAEL, E. L., I9I I. Classification and vertical distribution of the Chaetognatha of the San Diego region. Univ. Calif. Publ. Zool., Vol. 8, pp. 2 I-I86.

RuSSELL, F. S., I926. The vertical distribution of marine macroplankton. IV. The apparent importance of light intensity as a controlling factor in the behaviour of certain species in the Plymouth area. F. Mar. biol. Ass. U.K., Vol. I4, pp. 4I5-40.

- 1927. The vertical distribution of plankton in the sea. Biol. Rev., Vol. 2, pp. 213-62.

\section{ADDENDUM}

Since going to press a very interesting paper by Professor J. E. Harris has appeared, on the 'Physical factors involved in the vertical migration of plankton' (Quart. F. micr. Sci., Vol. 94, pp. 537-50, Dec. 1953). We cannot agree that all his conclusions, based upon the study of Daphnia magna, for example those concerning a negative geotaxis, can apply to all plankton animals which migrate vertically. It may however be significant that the animals which we found at times swimming horizontally were mainly those having, like his Daphnia, compound eyes: euphausians and decapod larvae (see p. 424). 